Clim. Past, 9, 2117-2133, 2013

www.clim-past.net/9/2117/2013/

doi:10.5194/cp-9-2117-2013

(C) Author(s) 2013. CC Attribution 3.0 License.

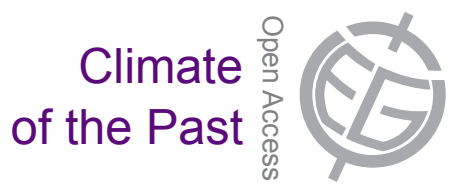

\title{
A mid-Holocene climate reconstruction for eastern South America
}

\author{
L. F. Prado ${ }^{1}$, I. Wainer ${ }^{1}$, C. M. Chiessi ${ }^{2}$, M.-P. Ledru ${ }^{3}$, and B. Turcq ${ }^{4}$ \\ ${ }^{1}$ Instituto Oceanográfico, Universidade de São Paulo, São Paulo, Brazil \\ ${ }^{2}$ Escola de Artes, Ciências e Humanidades, Universidade de São Paulo, São Paulo, Brazil \\ ${ }^{3}$ IRD UMR 226 Institut des Sciences de l'Evolution, IRD CNRS UM2, Montpellier, France \\ ${ }^{4}$ IRD UMR 7159 Laboratoire d'Océanographie et du Climat: Expérimentations et approches numériques, Bondy, France
}

Correspondence to: L. F. Prado (luciana.prado@usp.br)

Received: 14 November 2012 - Published in Clim. Past Discuss.: 29 November 2012

Revised: 10 July 2013 - Accepted: 27 July 2013 - Published: 9 September 2013

\begin{abstract}
The mid-Holocene (6000 calibrated years before present) is a key period in palaeoclimatology because incoming summer insolation was lower than during the late Holocene in the Southern Hemisphere, whereas the opposite happened in the Northern Hemisphere. However, the effects of the decreased austral summer insolation over South American climate have been poorly discussed by palaeodata syntheses. In addition, only a few of the regional studies have characterised the mid-Holocene climate in South America through a multiproxy approach. Here, we present a multiproxy compilation of mid-Holocene palaeoclimate data for eastern South America. We compiled 120 palaeoclimatological datasets, which were published in 84 different papers. The palaeodata analysed here suggest a water deficit scenario in the majority of eastern South America during the midHolocene if compared to the late Holocene, with the exception of northeastern Brazil. Low mid-Holocene austral summer insolation caused a reduced land-sea temperature contrast and hence a weakened South American monsoon system circulation. This scenario is represented by a decrease in precipitation over the South Atlantic Convergence Zone area, saltier conditions along the South American continental margin, and lower lake levels.
\end{abstract}

\section{Introduction}

Recently, the Last Glacial Maximum (LGM) and the midHolocene (MH) have been the foci of numerous studies using data-model approaches (Pinot et al., 1999; Wainer et al., 2005; Kageyama et al., 2006; Braconnot et al., 2007a, b; Melo and Marengo, 2008; Silva Dias et al., 2009; Carré et al., 2012; and others). The LGM and the MH, corresponding to 21000 calibrated years before present (cal yr BP) and $6000 \mathrm{cal}$ yr BP, respectively (Braconnot et al., 2007a), are usually chosen because of their different boundary conditions, if compared to the late Holocene (LH), that can be used to test the response of climatic models (Joussaume and Braconnot, 1997). During the LGM, Earth was covered by a larger amount of ice than during the $\mathrm{LH}$, whereas the $\mathrm{MH}$ was characterised by increased (decreased) summer insolation in the Northern (Southern) Hemisphere if compared to modern conditions. The change in insolation, particularly, was due to a difference of ca. $101^{\circ}$ between the MH longitude and the current longitude of the perihelion. As a consequence, the perihelion occurred at the austral spring equinox during the $\mathrm{MH}$, whereas today it is reached at the austral summer solstice (Joussaume and Braconnot, 1997). This caused a $\mathrm{MH}$ insolation decrease of ca. $20 \mathrm{~W} \mathrm{~m}^{-2}$ in southern latitudes from January to March compared to preindustrial values (Bosmans et al., 2012).

Data-model approaches require high-quality palaeoclimatic records and state-of-the-art climatic models. With this aim many projects have been carried out, such as the Climate: Long-range Investigation, Mapping, and Prediction (CLIMAP, CLIMAP Project Members, 1976, 1981, 1984), the Cooperative Holocene Mapping Project (COHMAP, COHMAP Members, 1988), and the Paleoclimate Modelling Intercomparison Project (PMIP, Braconnot et al., 2007a, b, 2012). PMIP is in its third phase, now part of the Coupled Model Intercomparison Project fifth phase (CMIP5, Taylor et al., 2012), and consists in evaluating the models' performance in reproducing the climate of the LGM, the $\mathrm{MH}$, and the last millennium. One implication of these projects 
is that the better climate models are able to reproduce past climates, the more reliably these models will project future climates. Climatic changes have been observed throughout Earth's history, and the ability to project future climates has great importance for planning and implementing adaptation and mitigation policies (Jansen et al., 2007). Yet, as in the CLIMAP and COHMAP initiatives, the state-of-the-art models included in PMIP3 must also be evaluated with regard to palaeodata. Hence, gathering records in the form of palaeodata syntheses is imperative.

In their supplementary information, Braconnot et al. (2012) present a summary of the available global and regional datasets for the $\mathrm{MH}$ and the LGM, derived from different proxies and archives. These efforts (Prentice and Webb III, 1998; Kohfeld and Harrison, 2000, 2001; Harrison et al., 2003; Kucera et al., 2005; Power et al., 2008; MARGO Project Members, 2009; Leduc et al., 2010; Bartlein et al., 2011) have been motivated by PMIP and other modelling projects. Nevertheless, all of these efforts have included only a few records from the Southern Hemisphere. Records from the MH in South America are particularly sparse if compared to records from other locations in the Northern Hemisphere and with those from the LGM (see, e.g. MARGO Project Members, 2009). Thus, the uncertainties in the palaeoclimate record for this continent are still large.

In this study, we present a compilation of multiproxy palaeoclimatic data from the MH for eastern South America. This compilation includes data from land, cave, lake, river, and ocean archives. Our objectives were the following: (i) to provide a spatial reconstruction of the MH patterns of precipitation, (ii) to provide a spatial reconstruction of the MH temperature patterns, (iii) to provide information on the MH lake levels and ocean salinity, and (iv) to determine the MH climatic drivers in South America based on the palaeodata information. Section 2 reviews the main aspects of the climate of South America and the South Atlantic Ocean which are necessary to understand the palaeodata. Section 3 presents the proxies used in this compilation, how the spatial and temporal domains were determined, the limitations of each proxy, and a chronological reliability index developed to evaluate and compare different types of proxies. Section 4 is dedicated to the results, while the discussion and conclusions are presented in Sect. 5.

\section{Climate of South America}

\subsection{South American monsoon system}

The term "South American monsoon system" (SAMS, Garreaud et al., 2009; Vera et al., 2006) was first used after Zhou and Lau (1998) because the summer atmospheric circulation in South America does not agree with the classical monsoon definition. The classical monsoon is defined as a seasonal inversion of the large-scale surface circulation pattern due to differential heating of the continents and the oceans. Zhou and Lau (1998) could not prove the existence of the South American monsoon by this criterion. Instead, they subtracted the annual wind from the winter and summer patterns and obtained a seasonal inversion of the easterlies anomalies. The result during austral summer is a circulation originating in the sub-Saharan region that crosses the equator and is driven southeastward by the Andes Cordillera (Fig. 1). In the Amazon Basin, a thermal low develops at the surface as a consequence of land heating. The winds of this circulation reach the Gran Chaco region in Paraguay and finally move clockwise, forming a low pressure system at the surface (Garreaud et al., 2009). Lenters and Cook (1995) identified five major regions of austral summer precipitation in South America: (1) the Amazon Basin; (2) the northern sector of the Andes, where precipitation is related to wind convergence at low levels and to the thermal low pressure at the surface; (3) the central sector of the Andes, where precipitation is due to the orography increase at the east side of the slope and to the meridional wind convergence; (4) the southern sector of the Andes, where precipitation is purely orographic; and (5) the South Atlantic Convergence Zone (SACZ, e.g. Carvalho et al., 2004), which is formed by wind convergence and moisture advection at low levels and by contribution of transient eddies moving equatorward. Another important circulation feature is the South American Low Level Jet (SALLJ, e.g. Marengo et al., 2004). It transports moisture from the Amazon Basin to the central southern South America. The SALLJ consists of a wind maximum at an altitude of 1 to $2 \mathrm{~km}$ and can influence the position and intensity of the SACZ (Marengo et al., 2004).

All mentioned features are present at low levels, but circulation at high levels in the atmosphere also shows characteristics linked to the SAMS (e.g. Marengo et al., 2012). The Bolivian High (BH) is the major summer feature at high levels and is a response to the latent heat released by rain clouds formed in the Amazon Basin. East of the BH, the Northeast Trough is observed as a return flux at high levels and is related to the subsidence over northeastern Brazil (Zhou and Lau, 1998). Both the BH and the Northeast Trough are associated with the SACZ at the surface (Lenters and Cook, 1997). The SACZ is the main convective system of South America, and is responsible for most of the austral summer precipitation in central and southeastern Brazil (Carvalho et al., 2004). It consists of a northwest-southeast-oriented cloud band that brings moisture from the Amazon region to central and southeastern Brazil. The SACZ is characterised by the coupling of the convergence zone with transient eddies from higher latitudes and can stay stationary for many days. Transient systems are responsible for a portion of precipitation in southeastern South America throughout the year, predominantly in southern and southeastern South America. Reboita et al. (2010) have found three major areas of cyclonic activity over the South Atlantic Ocean off eastern South America: Argentina (ca. $48^{\circ} \mathrm{S}$ ), the La Plata 


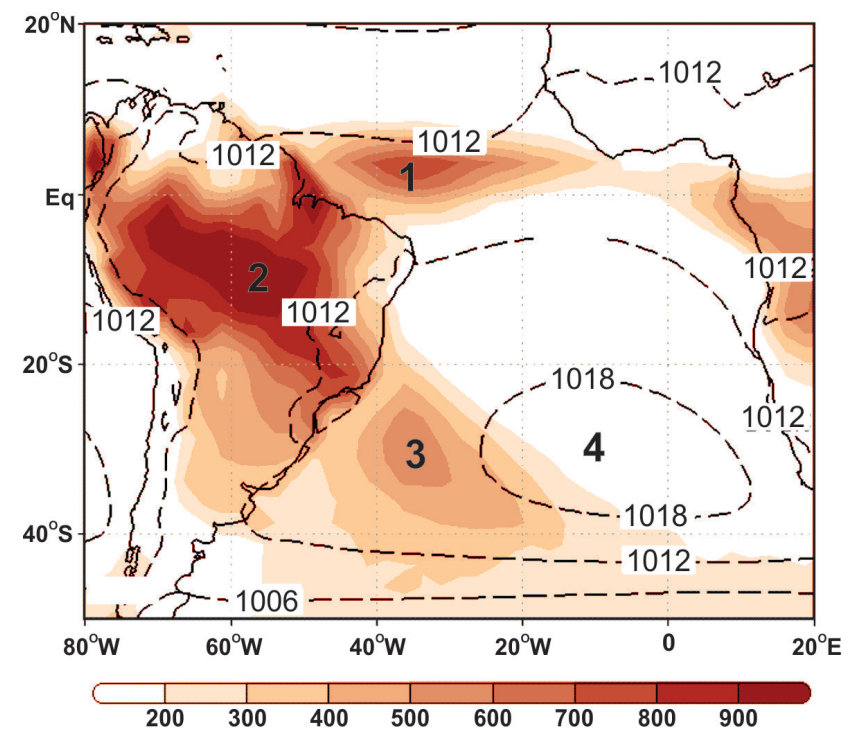

Fig. 1. Atmospheric mean circulation (1979-2010) at the surface level during austral summer (December to February), derived from ERA-Interim dataset (Dee et al., 2011). (1) Intertropical Convergence Zone (ITCZ); (2) and (3) South Atlantic Convergence Zone (SACZ), continental and oceanic components, respectively; (4) South Atlantic Subtropical High. Colours refer to mean precipitation during the December-January-February period, in millimetres $(\mathrm{mm})$; dashed black lines refer to mean sea level pressure, in hectopascals (hPa). Vertical axis refers to latitude values, and horizontal axis refers to longitude values.

river discharge between Argentina and Uruguay (ca. $35^{\circ} \mathrm{S}$ ), and the south/southeastern coast of Brazil. Sea surface temperatures (SST) over the South Atlantic Ocean can influence the intensity and position of the SACZ (Chaves and Nobre, 2004).

A large portion of the interannual variability of the SAMS can be explained by the El Niño-Southern Oscillation (ENSO, e.g. Trenberth et al., 1997); its warm (cold) phase is responsible for decreased (increased) precipitation during the wet season of northern South America and above (below) average precipitation in southeastern South America (Marengo et al., 2012, and references therein). The Southern Annular Mode (SAM, Visbeck, 2009) is also related to interannual variability of precipitation in southeastern South America. At interdecadal timescales, there is evidence of effects induced by the Pacific Decadal Oscillation (PDO, Mantua et al., 1997) and by the Atlantic Multidecadal Oscillation (AMO, Enfield et al., 2001) on the variability of the SAMS (Garcia and Kayano, 2008; Chiessi et al., 2009; Silva et al., 2011).

An important issue found in palaeoclimatological studies pertains to the differences and interactions between the Intertropical Convergence Zone (ITCZ) and the SAMS (Vuille et al., 2012). Both the ITCZ and the SAMS exhibit seasonal variability, but the ITCZ is a permanent feature of at- mospheric circulation affected by the annual cycle of insolation. This cyclicity impacts SST, whereas the SAMS reflects the land-sea thermal gradient. The ITCZ is essentially an oceanic phenomenon concentrated in the Northern Hemisphere (Takahashi and Battisti, 2007), whereas the SAMS occurs mainly over the South American continent. Furthermore, the SAMS is highly dependent on land topography, which keeps it over the continent, whereas the ITCZ moves around the equator (Vuille et al., 2012).

\subsection{South Atlantic Ocean Circulation}

The South Atlantic ocean circulation is part of the Atlantic Meridional Overturning Circulation (AMOC, e.g. Kuhlbrodt et al., 2007), which contributes to the global process of heat redistribution. The South Atlantic Ocean transports heat northward across the equator, and is therefore considered a particular basin (Srokosz et al., 2012). In the high latitudes of the North Atlantic, the surface ocean loses heat to the atmosphere. The result is the sinking of dense and cold waters, which are transported to the south at depth (Dickson and Brown, 1994).

In the South Atlantic Ocean, the surface currents found off eastern South America are the North Brazilian Current (NBC), South Equatorial Undercurrent (SEUC), South Equatorial Countercurrent (SECC), South Equatorial Current (SEC), Brazil Current (BC), and Malvinas Current (MC) (see Fig. 2a, after Peterson and Stramma, 1991).

Sea surface salinities (SSS) are strongly influenced by net precipitation/runoff. Accordingly, on the eastern South American continental margin, low SSS are found near the La Plata (ca. $35^{\circ} \mathrm{S}, 55^{\circ} \mathrm{W}$ ) and Amazon (ca. $0^{\circ}, 50^{\circ} \mathrm{W}$ ) river mouths, and further offshore beneath the ITCZ. Maximum SSS are found in the subtropics, due to strong evaporation in the region of the subtropical high (ca. $25^{\circ} \mathrm{S}, 10-40^{\circ} \mathrm{W}$ ) (Talley et al., 2012). SSTs have zonal distribution in the South Atlantic Ocean, with colder waters to the south and warmer waters to the north, ranging from 10 to $27^{\circ} \mathrm{C}$ (Fig. 2b) (Locarnini et al., 2010). At ca. $36^{\circ} \mathrm{S}$ the confluence of the $\mathrm{BC}$ (warm surface current) and the MC (cold surface current) is characterised by densely spaced surface isotherms on the eastern South American continental margin (Wainer et al., 2000). The equatorial Atlantic presents a tongue-shaped pattern in the SST field known as the Atlantic Niño (Zebiak, 1993; Chang et al., 2006).

The variability of the South Atlantic Ocean comprises time frequencies ranging from interannual to multidecadal periods (Enfield and Mayer, 1997; Venegas et al., 1998; Czaja and Frankignoul, 2002; Wainer et al., 2008). 


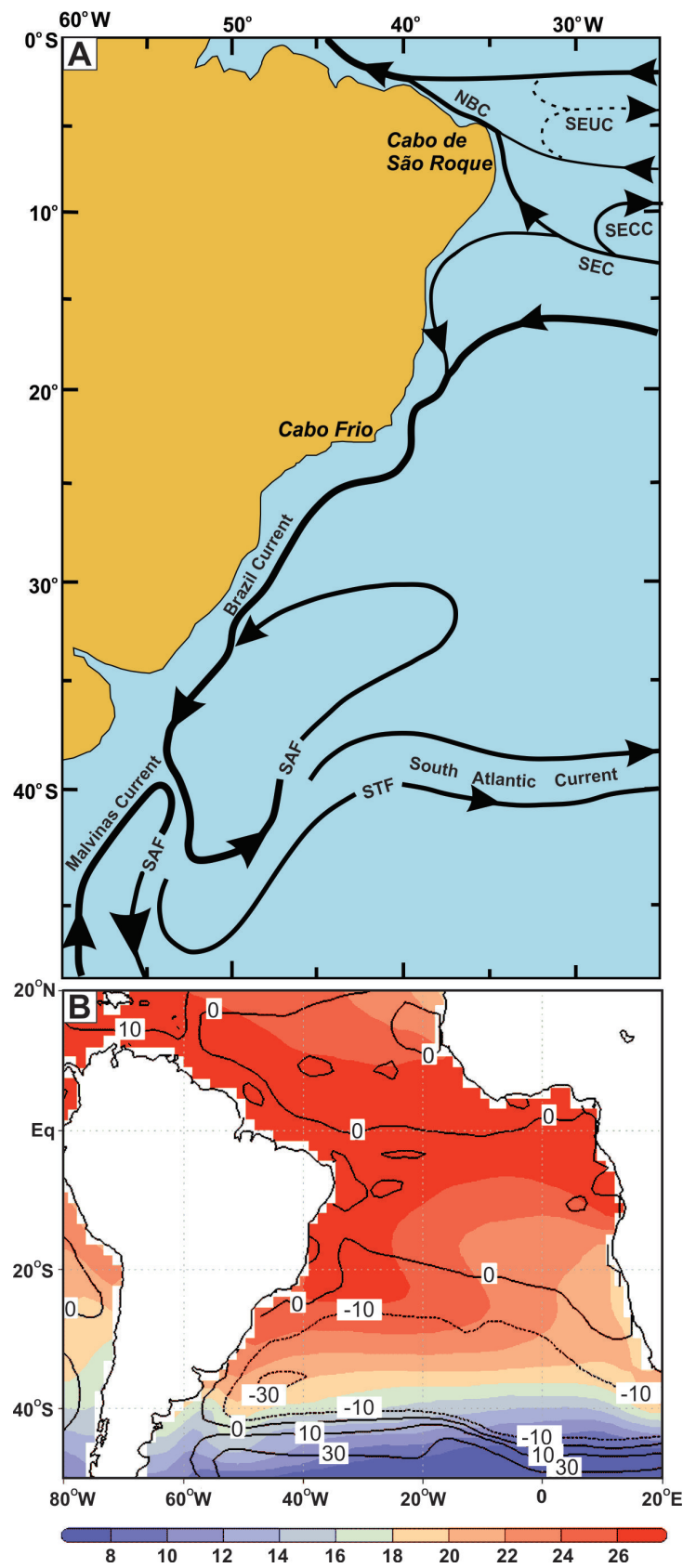

Fig. 2. The South Atlantic Ocean. (a) Upper-level barotropic currents and fronts on the Brazilian continental margin, western South Atlantic Ocean: NBC - North Brazilian Current; SEUC - South Equatorial Under Current; SECC - South Equatorial Countercurrent; SEC - South Equatorial Current; SAF - Subantarctic Front; STF - Subtropical Front; adapted from Peterson and Stramma (1991). (b) Austral summer (December to February) barotropic stream function in sverdrup (Sv) (dashed and solid lines, SalasMelia et al., 2005), and Era-Interim sea surface temperature in degrees Celsius $\left({ }^{\circ} \mathrm{C}\right)$ (shaded colours, Dee et al., 2011).
Table 1. Description of proxy types used in this study (modified from Wirtz et al., 2010).

\begin{tabular}{lll}
\hline Code & Proxy type & Description \\
\hline IF & $\begin{array}{l}\text { Isotopic oxy- } \\
\text { gen and car- } \\
\text { bon fractiona- } \\
\text { tion }\end{array}$ & $\delta^{18} \mathrm{O}, \delta^{13} \mathrm{C}$ \\
\hline $\mathrm{PC}$ & $\begin{array}{l}\text { Physico- } \\
\text { chemical }\end{array}$ & $\begin{array}{l}\mathrm{Mg} / \mathrm{Ca}, \mathrm{Ti} / \mathrm{Ca}, \mathrm{Fe} / \mathrm{Ca}, \mathrm{Fe} / \mathrm{Sr}, \\
\text { size, petrography, alkenone, thermo- } \\
\end{array}$ \\
& $\begin{array}{l}\text { luminescence, mineralogy, pH, Eh, } \\
\text { magnetic susceptibility }\end{array}$ \\
\hline $\mathrm{BI}$ & Biological & $\begin{array}{l}\text { Pollen, diatoms, spores, algae, mol- } \\
\text { luscs, sponge, organic matter, char- } \\
\text { coal, relative abundance }\end{array}$ \\
\hline & &
\end{tabular}

\section{Proxy data}

Our multiproxy compilation contains a large variety of archive and proxy types, and one must consider their limitations. Table 1 displays the classification of the palaeodata and the types of proxy used in our compilation. Our classification was based on Wirtz et al. (2010) (see Table 1 in Wirtz et al. (2010) for more details). The oxygen and carbon stable isotopic ratios are the fractionation-dependent proxies. The physico-chemical proxies comprise all geochemical ratios and physico-chemical approaches, whilst all information derived from organisms is classified as biological. We highlight that a substantial part (ca. $83 \%$ ) of the palaeodata analysed is classified as the latter type, with most being pollen assemblages. Pollen data mainly reflect temperature changes, but can also reveal changes in the rainfall regime, particularly in the tropics. The Araucaria forest is related to wet and cold climate (e.g. Behling, 1997), whereas the dominance of Poaceae and Asteraceae in the pollen spectra may correspond to dry and cold climate (e.g. Ledru et al., 2009).

\subsection{Data limitations}

Different proxies have distinct frequency dependence due to their inherent sensitivity to climate. Deep marine sediments typically have low resolution ( $>1 \mathrm{ka}$ ) because of their low sedimentation rate and bioturbation in non-anoxic zones, whereas high resolution, such as years or seasons, can be typically found in corals (Bradley, 1999). Another consideration should be made in respect to the different temporal responses from each type of proxy. The archived proxies can be affected by climatic changes immediately after the event, or they can have a delayed reaction. Vegetational data, such as pollen assemblages deposited in the Cariaco Basin (located off northern South America), show climatic inertia and tend to take at least $25 \pm 15 \mathrm{yr}$ to respond to 
abrupt climate changes (Hughen et al., 2004). Moreover, Huntley (2012) discussed the biological response of proxies to bioclimatic variables instead of to the climate itself, and argued that this response varies from one organism to another. This complicated relationship between biological proxies and climate exemplifies the difficulties in comparing different types of proxies. Furthermore, not all records are continuous in time. When dealing with biological records, one should also be aware of possible seasonal preferences. Planktonic foraminifera and coccolithophores are examples of organisms that carry a seasonal signal related to their biological cycles (Giraudeau and Beaufort, 2008).

\subsection{Temporal and spatial domains}

In this study, we used the ${ }^{14} \mathrm{C}$ ages as published by the authors of each examined paper. Thus, non-calibrated ages are expressed as yr BP, while calibrated ages are expressed as cal yr BP. Two main criteria were used to select the papers included in our compilation. The first one is the temporal definition of the $\mathrm{MH}$ period. The $\mathrm{MH}$ is usually referred to as 6000 cal yr BP (e.g. Braconnot et al., 2012); however, sampling errors related to the dating approach and the variable temporal resolution of the samples introduce uncertainties that should be taken into account. To account for these uncertainties, we considered the interval from 7000 to $5000 \mathrm{cal} \mathrm{yr} \mathrm{BP}$ as the period corresponding to the $\mathrm{MH}$.

Secondly, the spatial domain (Fig. 3) was defined based on physical parameters. The latitudinal limits used are the equator, and the mean latitude of the high-level westerlies (ca. 40 $\mathrm{S}$ ) (Peixoto and Oort, 1992). The westerlies can vary in latitudinal position throughout the year, from 30 to $60^{\circ} \mathrm{S}$ at the surface, and from 30 to $50^{\circ} \mathrm{S}$ at high levels in the atmosphere (Peixoto and Oort, 1992; Garreaud et al., 2009). None of the palaeorecords used in this compilation were under the direct influence of the westerlies. The longitudinal limits used are the $10^{\circ} \mathrm{W}$ meridian in the western South Atlantic Ocean for the eastern border of the domain, and the western border is characterised by altitudes below $2300 \mathrm{~m}$.

Considering the temporal and spatial domains defined above, we conducted a thorough investigation of published studies containing $\mathrm{MH}$ climatic information from South America. Table 2 contains the location, proxy type, and reference for each paper examined. We compiled 120 palaeoclimatological datasets from the analysis of 84 studies using the original published chronologies. Some papers included different analyses or an update of cores examined previously. Figure 3 shows the spatial distribution of the records included in this study. The numbers on the map identify each sample location as listed in Table 2.

\subsection{Dating uncertainty}

To evaluate the dating uncertainty of the palaeodata, we have created a chronological reliability index $(Q)$ based on the sampling resolution and the sample age model:

$Q=\frac{\mathrm{CA}+R+D}{3}$.

CA (calibration) equals 1 if ages are calibrated, or 0 if they are not calibrated. $R$ (resolution) refers to the mean number of samples per core length ratio, where

$$
R=\left\{\begin{array}{c}
0.1 \text { for ratio between } 0.01 \text { and } 0.1 \\
0.2 \text { for ratio between } 0.11 \text { and } 0.2 \\
\vdots \\
11.0 \text { for ratio between } 10.01 \text { and } 11.00
\end{array}\right\}
$$

$D$ (dating) is the number of datings within the interval $7000-5000$ cal yr BP, divided by 10 . This index is a semiquantitative approach that simply involves the computation of an arithmetic mean, where the same weight is given to all parameters. Therefore, because $Q$ encompasses a sum, the greater its value, the higher the chronological reliability of the palaeodata.

\section{Results}

Figures 4 to 8 show results of the $Q$ index applied to the compiled palaeodata. Larger symbols refer to data with a higher chronological reliability. It is important to note that all of the climatic information we present is based on the authors' conclusions in each paper used in this compilation and do not imply any further interpretation.

\subsection{Precipitation}

Precipitation and moisture are the most abundant variables in the palaeodata for two reasons: (i) these variables are the main type of information obtained from pollen assemblages, and (ii) pollen assemblages constitute the main type of proxy records found in eastern South America during the MH (Fig. 4). The general MH scenario corresponds to a drier eastern South America than during the LH, except for northeastern Brazil, which exhibits an unclear climate signal during the MH. A similar climatic scenario has already been discussed (Valdes, 2000; Cruz et al., 2009; Silva Dias et al., 2009). Valdes (2000) described drier conditions in South America (except for northeastern Brazil) during the MH austral summer (from December to February), derived from the first phase of PMIP data models. Cruz et al. (2009) compared speleothem-based precipitation records to vertical velocity, geopotential, and oxygen isotopes fields simulated by a numerical model and obtained an east-west antiphase of these variables over tropical South America. Oxygen isotopic values capture the precipitation variability because the isotopic fractionation in the area depends on the path the water takes from its source to its sink; the greater the distance, the greater the loss of the heavier isotopes (Vuille et al., 2012). Thus, this 


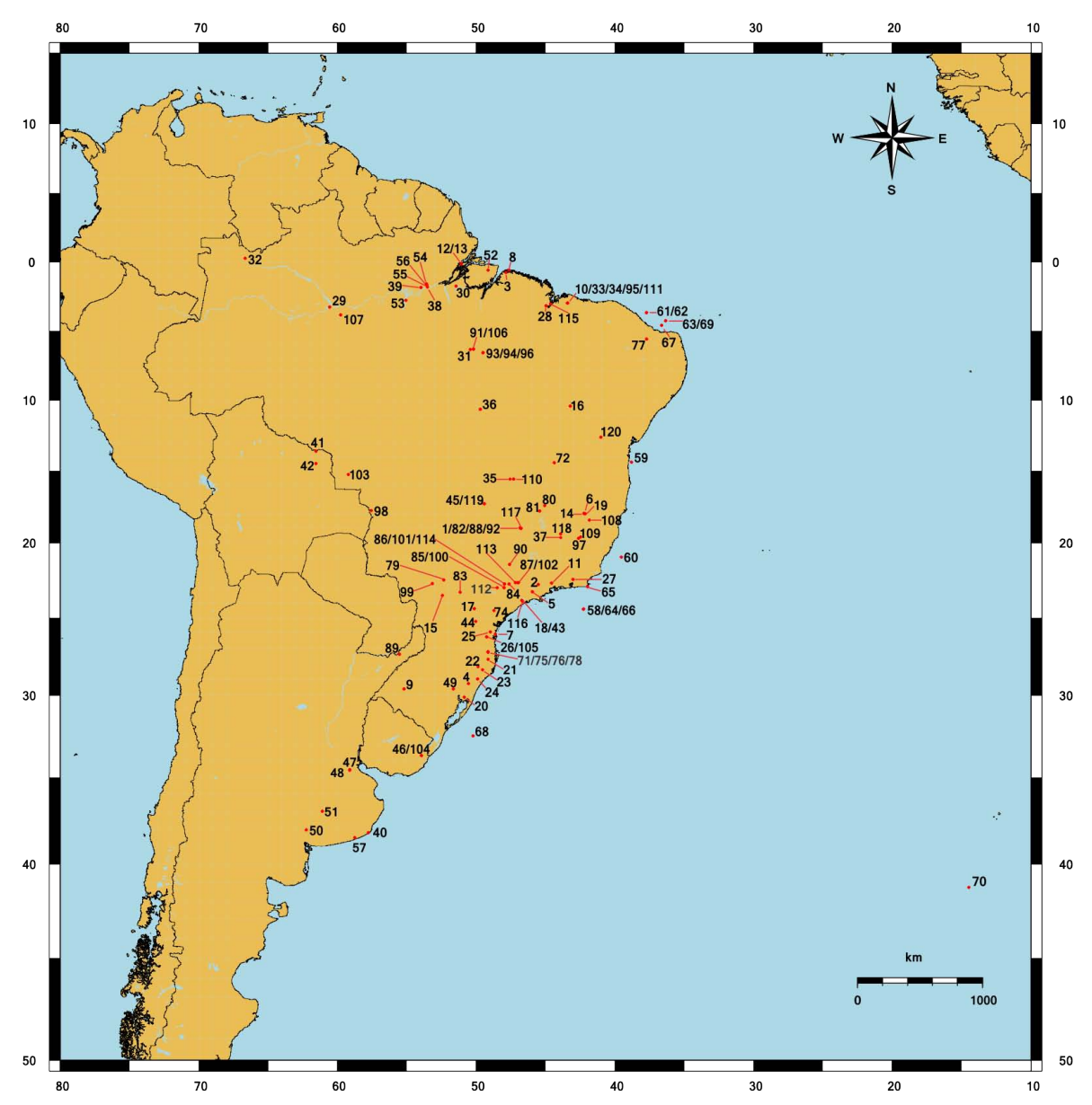

Fig. 3. Spatial distribution of the 120 palaeorecords (from 84 studies) used in this study. Vertical axis refers to latitude, and horizontal values correspond to longitude. Details for each record are found in Table 2.

ratio may have different interpretations depending on the site of the record. In southeastern South America the oxygen isotopic ratio is related to the SAMS activity versus moisture derived from the adjacent subtropical South Atlantic Ocean (e.g. Cruz Jr. et al., 2005). Silva Dias et al. (2009) have examined two MH numerical runs: the first one only considered variations in the orbital parameters, and the second one included changes in vegetation. The former run presented results very similar to Valdes (2000) and Cruz et al. (2009), characterised by a drier-than-modern $\mathrm{MH}$ climate in South America during the wet season (December to February), except for northeastern Brazil. The latter run resulted in a northward displacement of the SACZ and a southward migration of the ITCZ during the $\mathrm{MH}$ austral summer when compared to the run without changes in vegetation.

Climatic information extracted from lake level proxies is shown in Fig. 5. Lake levels were lower than modern levels for all analysed sites, which corroborates the precipitation/moisture palaeodata (Fig. 4). This characterises a drier climate in eastern South America during the MH compared to the LH. $Q$-index values of the lake level proxy records are low, with the highest ones located in the eastern Amazon.

Palaeorecords of SSS from the South American continental margin (Fig. 6) are scarce. There are few salinity palaeorecords mainly because of the difficulties in collecting appropriate marine sediment cores. However, all records but one show saltier conditions along the South American continental margin during the $\mathrm{MH}$ if compared to the $\mathrm{LH}$. Higher $Q$-index values are found off northeastern Brazil and on the Argentinean continental margin.

\subsection{Temperature}

Figure 7 shows air temperature palaeodata for the MH. The majority of samples were collected in Uruguay and centralsouthern Brazil. High $Q$-index data can be found near the equator and in southern Brazil. The records depicted in Fig. 7 indicate a warmer climate in southern Brazil and a climate similar to the LH in the north-northeastern Brazil.

Difficulties in collecting marine sediment cores also affect the amount of SST proxy records (Fig. 8) for the MH off 
Table 2. Locations and references of the palaeoclimatic records used in this study*. Abbreviations are as follows. Site: $\mathrm{Lk}=$ lake, $\mathrm{Cv}=$ cave, $\mathrm{Rv}=$ river; proxy type: $\mathrm{IF}=$ isotopic fractionation, $\mathrm{PC}=$ physico-chemical, $\mathrm{BI}=$ biological. Numbers within parentheses in the "Site" column - in records 72, 77, 90, 95, 112, and 113 - refer to total of samples collected at the referred site. More details of proxy type can be found in Table 1.

\begin{tabular}{|c|c|c|c|c|c|}
\hline No. & Site & Proxy type & Reference & Lat. $\left(^{\circ}\right)$ & Long. $\left({ }^{\circ}\right)$ \\
\hline 1 & Salitre de Minas & $\mathrm{BI}$ & Ledru (1993) & -19.00 & -46.77 \\
\hline 2 & Morro de Itapeva & $\mathrm{BI}$ & Behling (1997a) & -22.78 & -45.53 \\
\hline 3 & Curuça Lk & $\mathrm{BI}$ & Behling (2001) & -0.77 & -47.85 \\
\hline 4 & São Francisco de Paula & $\mathrm{BI}$ & Behling et al. (2001a) & -29.24 & -50.57 \\
\hline 5 & Jacareí peat & $\mathrm{BI}$ & Garcia et al. (2004) & -23.28 & -45.97 \\
\hline 6 & Nova Lk & BI & Behling (2003) & -17.97 & -42.20 \\
\hline 7 & Volta Velha & $\mathrm{BI}$ & Behling and Negrelle (2001) & -26.07 & -48.63 \\
\hline 8 & Crispim Lk & $\mathrm{BI} / \mathrm{PC}$ & Behling and Costa (2001) & -0.59 & -47.65 \\
\hline 9 & São Francisco de Assis & BI & Behling et al. (2005) & -29.59 & -55.22 \\
\hline 10 & Caçó Lk & $\mathrm{IF} / \mathrm{BI}$ & Ledru et al. (2006) & -2.96 & -43.42 \\
\hline 11 & Serra da Bocaina & $\mathrm{BI}$ & Behling et al. (2007) & -22.71 & -44.57 \\
\hline 12 & Marcio Lk & $\mathrm{BI}$ & De Toledo and Bush (2007) & -0.13 & -51.08 \\
\hline 13 & Tapera Lk & BI & De Toledo and Bush (2007) & -0.13 & -51.08 \\
\hline 14 & Aleixo Lk & $\mathrm{IF} / \mathrm{PC} / \mathrm{BI}$ & Enters et al. (2010) & -17.99 & -42.12 \\
\hline 15 & Fazenda Lk & $\mathrm{BI}$ & Resende (2010) & -23.51 & -52.45 \\
\hline 16 & Saquinho Rv & $\mathrm{BI} / \mathrm{PC}$ & De Oliveira et al. (1999) & -10.40 & -43.22 \\
\hline 17 & Serra Campos Gerais & $\mathrm{BI}$ & Behling (1997b) & -24.40 & -50.13 \\
\hline 18 & Colônia & BI & Ledru et al. (2009) & -23.87 & -46.71 \\
\hline 19 & Pires Lk & $\mathrm{BI}$ & Behling (1995a) & -17.95 & -42.22 \\
\hline 20 & Águas Claras & BI & Bauermann et al. (2003) & -30.10 & -50.85 \\
\hline 21 & Serra da Boa Vista & $\mathrm{BI}$ & Behling (1995b) & -27.70 & -49.15 \\
\hline 22 & Morro da Igreja & BI & Behling (1995b) & -28.18 & -49.87 \\
\hline 23 & Serra do Rio Rastro & $\mathrm{BI}$ & Behling (1995b) & -28.38 & -49.55 \\
\hline 24 & Cambará do Sul & $\mathrm{BI}$ & Behling et al. (2004) & -28.95 & -49.90 \\
\hline 25 & Serra do Araçatuba & $\mathrm{BI}$ & Behling (2007) & -25.92 & -48.98 \\
\hline 26 & Cerro do Touro & $\mathrm{IF} / \mathrm{PC} / \mathrm{BI}$ & Oliveira et al. (2008a) & -26.25 & -49.25 \\
\hline 27 & Serra dos Órgãos & $\mathrm{BI}$ & Behling and Safford (2010) & -22.46 & -43.03 \\
\hline 28 & Aquiri Lk & $\mathrm{BI} / \mathrm{PC}$ & Behling and Costa (1997) & -3.17 & -44.98 \\
\hline 29 & Calado Lk & $\mathrm{BI} / \mathrm{PC}$ & Behling et al. (2001b) & -3.27 & -60.58 \\
\hline 30 & Curuá Rv & $\mathrm{BI} / \mathrm{PC}$ & Behling and Costa (2000) & -1.74 & -51.46 \\
\hline 31 & Serra Sul de Carajás - Lk & $\mathrm{BI}$ & Absy et al. (1991) & -6.33 & -50.42 \\
\hline 32 & Pata Lk & $\mathrm{BI}$ & Colinvaux et al. (1996) & 0.27 & -66.68 \\
\hline 33 & Caçó Lk & $\mathrm{BI}$ & Ledru et al. (2002) & -2.96 & -43.42 \\
\hline 34 & Caçó Lk & $\mathrm{IF} / \mathrm{BI}$ & Ledru et al. (2006) & -2.96 & -43.42 \\
\hline 35 & Águas Emendadas & $\mathrm{BI}$ & Barberi et al. (2000) & -15.57 & -47.58 \\
\hline 36 & Confusão Lk & $\mathrm{BI}$ & Behling (2002b) & -10.63 & -49.72 \\
\hline 37 & Santa Lk & $\mathrm{BI}$ & Parizzi et al. (1998) & -19.63 & -43.90 \\
\hline 38 & Geral Lk & $\mathrm{BI} / \mathrm{PC}$ & Bush et al. (2000) & -1.80 & -53.53 \\
\hline 39 & Comprida Lk & $\mathrm{BI} / \mathrm{PC}$ & Bush et al. (2000) & -1.86 & -53.98 \\
\hline 40 & Arr. Las Brusquitas - Rv & $\mathrm{BI}$ & Vilanova et al. (2006b) & -38.23 & -57.77 \\
\hline 41 & Bella Vista Lk & $\mathrm{BI}$ & Mayle et al. (2000) & -13.62 & -61.55 \\
\hline 42 & Chaplin Lk & $\mathrm{BI}$ & Mayle et al. (2000) & -14.47 & -61.55 \\
\hline 43 & Colônia & $\mathrm{BI}$ & Ledru et al. (2005) & -23.87 & -46.71 \\
\hline 44 & Dourada Lk & $\mathrm{IF} / \mathrm{PC} / \mathrm{BI}$ & Moro et al. (2004) & -25.24 & -50.04 \\
\hline 45 & Cromínia & $\mathrm{BI}$ & Salgado-Labouriau et al. (1997) & -17.28 & -49.42 \\
\hline 46 & India Muerta & $\mathrm{BI}$ & Iriarte (2006) & -33.70 & -53.95 \\
\hline 47 & Puente de la Tropa - Rv & $\mathrm{BI} / \mathrm{PC}$ & Prieto et al. (2004) & -34.58 & -59.14 \\
\hline 48 & Paso de Corro - Rv & $\mathrm{BI} / \mathrm{PC}$ & Prieto et al. (2004) & -34.55 & -59.12 \\
\hline 49 & Serra Geral & BI & Leal and Lorscheitter (2007) & -29.60 & -51.65 \\
\hline 50 & Arr. Sauce Chico - Rv & $\mathrm{BI}$ & Prieto (1996) & -38.08 & -62.26 \\
\hline 51 & Empalme Querandies & $\mathrm{BI}$ & Prieto (1996) & -37.00 & -61.11 \\
\hline 52 & Arari Lk & $\mathrm{BI}$ & Smith et al. (2011) & -0.60 & -49.14 \\
\hline
\end{tabular}


Table 2. Continued.

\begin{tabular}{|c|c|c|c|c|c|}
\hline No. & Site & Proxy type & Reference & Lat. $\left(^{\circ}\right)$ & Long. $\left({ }^{\circ}\right)$ \\
\hline 53 & Tapajós Lk & $\mathrm{BI} / \mathrm{PC}$ & Irion et al. (2006) & -2.79 & -55.08 \\
\hline 54 & Santa Maria Lk & $\mathrm{BI}$ & Bush et al. (2007) & -1.58 & -53.60 \\
\hline 55 & Saracuri Lk & $\mathrm{BI}$ & Bush et al. (2007) & -1.68 & -53.57 \\
\hline 56 & Geral Lk & $\mathrm{BI}$ & Bush et al. (2007) & -1.65 & -53.59 \\
\hline 57 & Quequén Grande Rv & $\mathrm{BI} / \mathrm{PC}$ & Hassan et al. (2009) & -38.50 & -58.75 \\
\hline 58 & South Atlantic Oc & $\mathrm{IF} / \mathrm{BI}$ & Toledo et al. (2007) & -24.43 & -42.28 \\
\hline 59 & South Atlantic Oc & $\mathrm{IF} / \mathrm{BI}$ & Toledo et al. (2007) & -14.40 & -38.82 \\
\hline 60 & South Atlantic Oc & $\mathrm{IF} / \mathrm{BI}$ & Toledo et al. (2007) & -20.95 & -39.53 \\
\hline 61 & South Atlantic Oc & IF & Arz et al. (1998) & -3.67 & -37.72 \\
\hline 62 & South Atlantic Oc & $\mathrm{IF} / \mathrm{PC}$ & Arz et al. (1998) & -3.67 & -37.72 \\
\hline 63 & South Atlantic Oc & $\mathrm{IF} / \mathrm{PC}$ & Arz et al. (2001) & -4.25 & -36.35 \\
\hline 64 & South Atlantic Oc & $\mathrm{BI}$ & Toledo et al. (2008) & -24.43 & -42.28 \\
\hline 65 & South Atlantic Oc & $\mathrm{BI} / \mathrm{PC}$ & Nagai et al. (2009) & -22.94 & -41.98 \\
\hline 66 & South Atlantic Oc & IF & Pivel et al. (2010) & -24.43 & -42.28 \\
\hline 67 & South Atlantic Oc & $\mathrm{IF} / \mathrm{PC}$ & Weldeab et al. (2006) & -4.61 & -36.64 \\
\hline 68 & South Atlantic Oc & $\mathrm{PC}$ & Chiessi et al. (2010) & -32.50 & -50.24 \\
\hline 69 & South Atlantic Oc & $\mathrm{PC}$ & Jaeschke et al. (2007) & -4.25 & -36.35 \\
\hline 70 & South Atlantic & $\mathrm{IF} / \mathrm{PC}$ & Groeneveld and Chiessi (2011) & -41.27 & -14.49 \\
\hline 71 & Botuverá Cv & $\mathrm{IF}$ & Cruz et al. (2005) & -27.22 & -49.15 \\
\hline 72 & Lapa Grande Cv (2) & IF & Stríkis et al. (2011) & -14.42 & -44.36 \\
\hline 73 & Botuverá $\mathrm{Cv}$ & IF & Wang et al. (2007) & -27.22 & -49.15 \\
\hline 74 & Santana Cv & IF & Cruz et al. (2006a) & -24.53 & -48.72 \\
\hline 75 & Botuverá $\mathrm{Cv}$ & IF & Cruz et al. (2006b) & -27.22 & -49.15 \\
\hline 76 & Botuverá Cv & $\mathrm{IF} / \mathrm{PC}$ & Cruz et al. (2007) & -27.22 & -49.15 \\
\hline 77 & Rio Grande do Norte - Cv (2) & IF & Cruz et al. (2009) & -5.60 & -37.73 \\
\hline 78 & Botuverá Cv (2) & IF & Wang et al. (2006) & -27.22 & -49.15 \\
\hline 79 & Taquarussu - Rv & BI & Parolin et al. (2006) & -22.50 & -52.33 \\
\hline 80 & Buritizeiro & $\mathrm{BI}$ & Lorente et al. (2010) & -17.41 & -45.06 \\
\hline 81 & Vereda Laçador & $\mathrm{BI}$ & Cassino (2011) & -17.81 & -45.43 \\
\hline 82 & Salitre de Minas & $\mathrm{IF} / \mathrm{PC} / \mathrm{BI}$ & Pessenda et al. (1996) & -19.00 & -46.77 \\
\hline 83 & Londrina & $\mathrm{IF} / \mathrm{PC} / \mathrm{BI}$ & Pessenda et al. (2004a) & -23.30 & -51.17 \\
\hline 84 & Piracicaba & $\mathrm{IF} / \mathrm{PC} / \mathrm{BI}$ & Pessenda et al. (2004a) & -22.77 & -47.63 \\
\hline 85 & Botucatu & $\mathrm{IF} / \mathrm{PC} / \mathrm{BI}$ & Pessenda et al. (2004a) & -23.00 & -48.00 \\
\hline 86 & Anhembi & $\mathrm{IF} / \mathrm{PC} / \mathrm{BI}$ & Pessenda et al. (2004a) & -22.75 & -47.97 \\
\hline 87 & Jaguariúna & $\mathrm{IF} / \mathrm{PC} / \mathrm{BI}$ & Pessenda et al. (2004a) & -22.67 & -47.02 \\
\hline 88 & Salitre de Minas & $\mathrm{IF} / \mathrm{PC} / \mathrm{BI}$ & Pessenda et al. (2004a) & -19.00 & -46.77 \\
\hline 89 & Misiones & $\mathrm{IF} / \mathrm{PC}$ & Zech et al. (2009) & -27.39 & -55.52 \\
\hline 90 & Tamanduá Rv (17) & $\mathrm{PC}$ & Turcq et al. (1997) & -21.45 & -47.60 \\
\hline 91 & Serra Sul de Carajás - Lk & $\mathrm{BI}$ & Servant et al. (1993) & -6.30 & -50.20 \\
\hline 92 & Salitre de Minas & $\mathrm{BI}$ & Servant et al. (1993) & -19.00 & -46.77 \\
\hline 93 & Serra Sul de Carajás - Lk & $\mathrm{IF} / \mathrm{PC}$ & Sifeddine et al. (1994) & -6.58 & -49.50 \\
\hline 94 & Serra Sul de Carajás - Lk & $\mathrm{IF} / \mathrm{PC} / \mathrm{BI}$ & Sifeddine et al. (2001) & -6.58 & -49.50 \\
\hline 95 & Caçó Lk (2) & $\mathrm{IF} / \mathrm{PC} / \mathrm{BI}$ & Jacob et al. (2004) & -2.96 & -43.42 \\
\hline 96 & Serra Sul de Carajás - Lk & $\mathrm{IF} / \mathrm{PC} / \mathrm{BI}$ & Sifeddine et al. (2004) & -6.58 & -49.50 \\
\hline 97 & Dom Helvécio Lk & $\mathrm{IF} / \mathrm{PC} / \mathrm{BI}$ & Sifeddine et al. (2004) & -19.68 & -42.63 \\
\hline 98 & La Gaiba Lk (2) & $\mathrm{BI}$ & Whitney et al. (2011) & -17.75 & -57.58 \\
\hline 99 & Paraná Rv (25) & $\mathrm{BI} / \mathrm{PC}$ & Stevaux (2000) & -22.72 & -53.17 \\
\hline 100 & Botucatu & $\mathrm{IF} / \mathrm{PC} / \mathrm{BI}$ & Gouveia et al. (2002) & -23.00 & -48.00 \\
\hline 101 & Anhembi & $\mathrm{IF} / \mathrm{PC} / \mathrm{BI}$ & Gouveia et al. (2002) & -22.75 & -47.97 \\
\hline 102 & Jaguariúna & $\mathrm{IF} / \mathrm{PC} / \mathrm{BI}$ & Gouveia et al. (2002) & -22.67 & -47.02 \\
\hline 103 & Pontes e Lacerda & $\mathrm{IF} / \mathrm{PC} / \mathrm{BI}$ & Gouveia et al. (2002) & -15.27 & -59.22 \\
\hline 104 & India Muerta & $\mathrm{BI}$ & Iriarte et al. (2004) & -33.70 & -53.95 \\
\hline 105 & Campo Alegre & $\mathrm{IF} / \mathrm{PC} / \mathrm{BI}$ & Oliveira et al. (2008b) & -26.25 & -49.25 \\
\hline 106 & Serra Norte Carajás - Lk & $\mathrm{BI} / \mathrm{PC}$ & Turcq et al. (2002) & -6.30 & -50.20 \\
\hline
\end{tabular}


Table 2. Continued.

\begin{tabular}{llllrr}
\hline No. & Site & Proxy type & Reference & Lat. $\left({ }^{\circ}\right)$ & Long. $\left({ }^{\circ}\right)$ \\
\hline 107 & Caracarana Lk & BI/PC & Turcq et al. (2002) & -3.84 & -59.78 \\
108 & Água Preta de Baixo Lk & BI/PC & Turcq et al. (2002) & -18.42 & -41.83 \\
109 & Dom Helvécio Lk & BI/PC & Turcq et al. (2002) & -19.68 & -42.59 \\
110 & Feia Lk & BI/PC & Turcq et al. (2002) & -15.57 & -47.30 \\
111 & Caçó Lk & IF/BI & Pessenda et al. (2005) & -2.96 & -43.42 \\
112 & Botucatu (2) & IF/BI & Scheel-Ybert et al. (2003) & -22.85 & -48.48 \\
113 & Jaguariúna (2) & IF/BI & Scheel-Ybert et al. (2003) & -22.67 & -47.17 \\
114 & Anhembi & IF/BI & Scheel-Ybert et al. (2003) & -22.75 & -47.97 \\
115 & Barreirinhas & IF/PC & Pessenda et al. (2004b) & -3.03 & -44.65 \\
116 & Curucutu & IF/PC/BI & Pessenda et al. (2009) & -23.93 & -46.65 \\
117 & Serra Negra Lk & BI & De Oliveira (1992) & -18.95 & -46.83 \\
118 & Olhos Lk & BI & De Oliveira (1992) & -19.38 & -43.90 \\
119 & Cromínia & BI & Ferraz-Vicentini and Salgado-Labouriau (1996) & -17.28 & -49.42 \\
120 & Paixão Cv & IF & Barreto (2010) & -12.63 & -41.02 \\
\hline
\end{tabular}

* The data published in this paper will be available through Pangaea (http://www.pangaea.de) as soon as the manuscript is accepted for publication. The available information on Pangaea include publication details, core details (name, location, latitude, longitude, elevation, coring device, core length), sample details (analytical method, samples treatment, sample interval, number of samples), dating details (number of datings within MH, calibration), climatic information (period, description, and evidences of changes observed), and values of the $Q$ index.

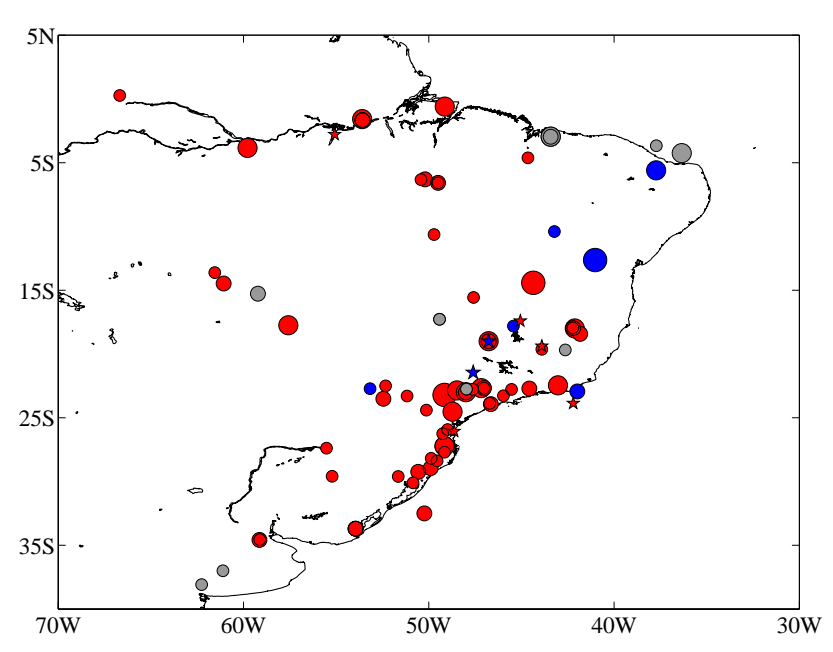

Fig. 4. MH precipitation/moisture palaeodata in eastern South America. Symbol colours: blue circles, wetter than modern; red circles, drier than modern; grey circles, similar to modern; red stars, dry-to-wet transition; and blue stars, wet-to-dry transition. Symbol size refers to palaeodata $Q$-index (a chronological reliability index; see text for more information) values; larger symbols indicate higher $Q$-index values. Vertical axis refers to latitude values, and horizontal axis refers to longitude values.

eastern South America. Despite the scarcity of SST records, the following pattern stands out: SST was lower than during the LH on the southeastern Brazilian continental margin, SST was higher/similar to the LH in the northeastern Brazilian continental margin, and SST was higher than during the LH over the Mid-Atlantic Ridge. However, $Q$-index values from these data are generally low.

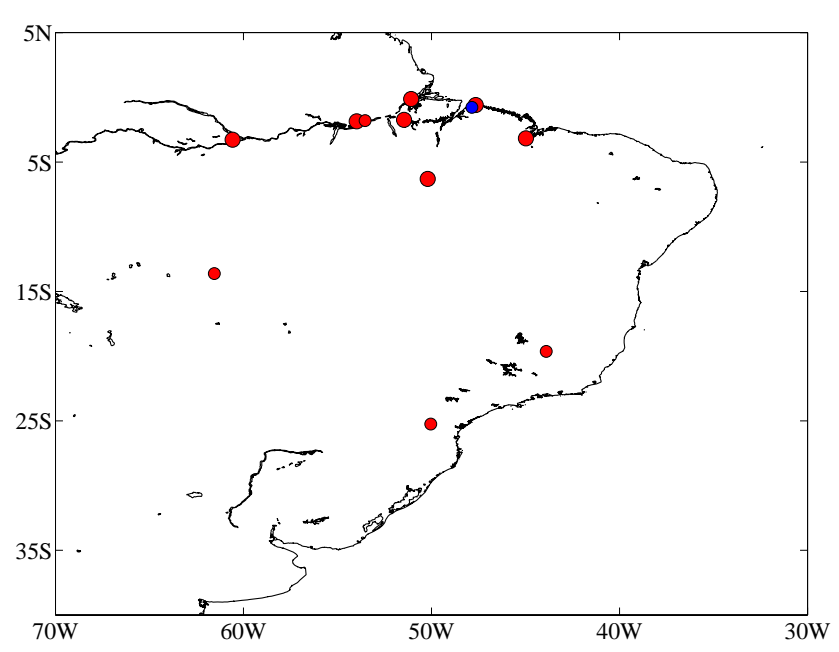

Fig. 5. MH lake level palaeodata in eastern South America. Symbol colours: red, lower than present; and blue, higher than present. Symbol size refers to palaeodata $Q$-index (a chronological reliability index; see text for more information) values; larger symbols indicate higher $Q$-index values. Vertical axis refers to latitude values, and horizontal axis refers to longitude values.

\section{Discussion and conclusions}

The evidence mentioned above indicates a significantly different scenario regarding $\mathrm{MH}$ precipitation over eastern South America if compared to the LH. The summarised records suggest an overall drier $\mathrm{MH}$ climate than during the LH in eastern South America, with the exception of northeastern Brazil (Figs. 4, 5). This pattern extends from 45 to $60^{\circ} \mathrm{W}$, and from 0 to $35^{\circ} \mathrm{S}$. Wetter climate than during the LH can be found locally on the coast of the states of São 


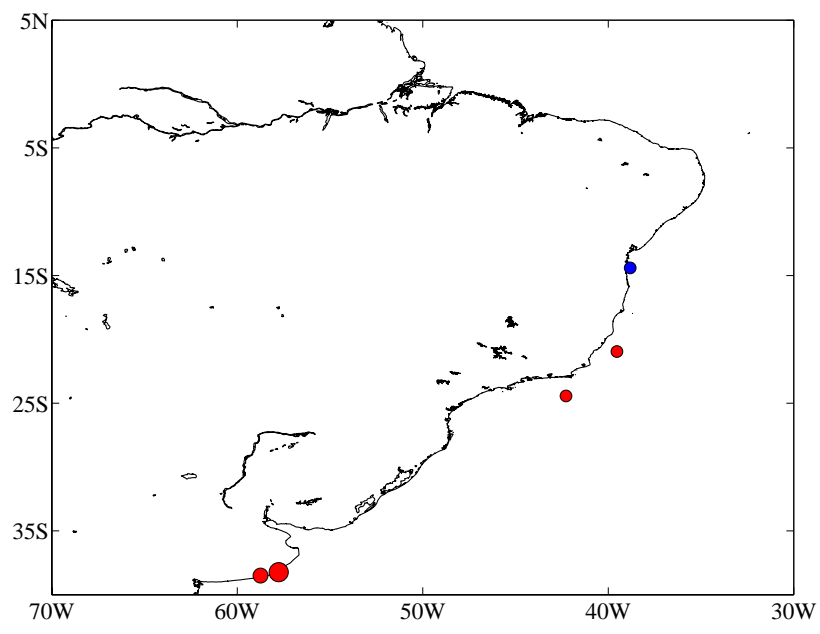

Fig. 6. MH salinity palaeodata off eastern South America. Symbol colours: blue circle, fresher than present; and red circles, saltier than present. Symbol size refers to palaeodata $Q$-index (a chronological reliability index; see text for more information) values; larger symbols indicate higher $Q$-index values. Vertical axis refers to latitude values, and horizontal axis refers to longitude values.

Paulo (ca. $23^{\circ} \mathrm{S}, 43^{\circ} \mathrm{W}$; Nagai et al., 2009) and in the state of Minas Gerais (ca. $18^{\circ} \mathrm{S}, 43^{\circ} \mathrm{W}$, e.g. Cassino, 2011).

Drier climatic conditions during the MH compared to the LH are portrayed by the replacement of wet forests by shrubs and grasslands in some regions, as suggested by pollen analyses (e.g. Behling and Safford, 2010, and others in Fig. 4). A drier MH climate can also be observed in proxies indicating lower lake levels than during the LH all across eastern South America (Fig. 5).

The land-sea temperature gradient is the major driver of the SAMS circulation (e.g. Vera et al., 2006). During the $\mathrm{MH}$, lower than $\mathrm{LH}$ values of austral summer insolation in the Southern Hemisphere induced a less effective land-sea contrast. Less energy was available at the surface and diminished the ascendant motion. Rain cloud formation was impaired, characterising a drier climate if compared to the LH in the SAMS area. The release of latent heat by these clouds is responsible for the establishment of the $\mathrm{BH}$, which is linked to the Northeast Trough (e.g. Marengo et al., 2012). Consequently, high-level atmospheric circulation was also smoothed, and the subsidence over northeastern Brazil was below modern average, generating more southern incursions of the ITCZ and precipitation in this region.

Coastal palaeodata indicate wetter/similar conditions to the LH (Fig. 4) (e.g. Nagai et al., 2009). Regional circulation features such as the land-sea breeze and winds associated with the position and intensity of the South Atlantic subtropical high can be related to the coastal areas that were wetter during the MH if compared to the LH. The land-sea breeze may have also been enhanced by a higher sea level during the MH (e.g. Angulo et al., 2006). It is noteworthy that the

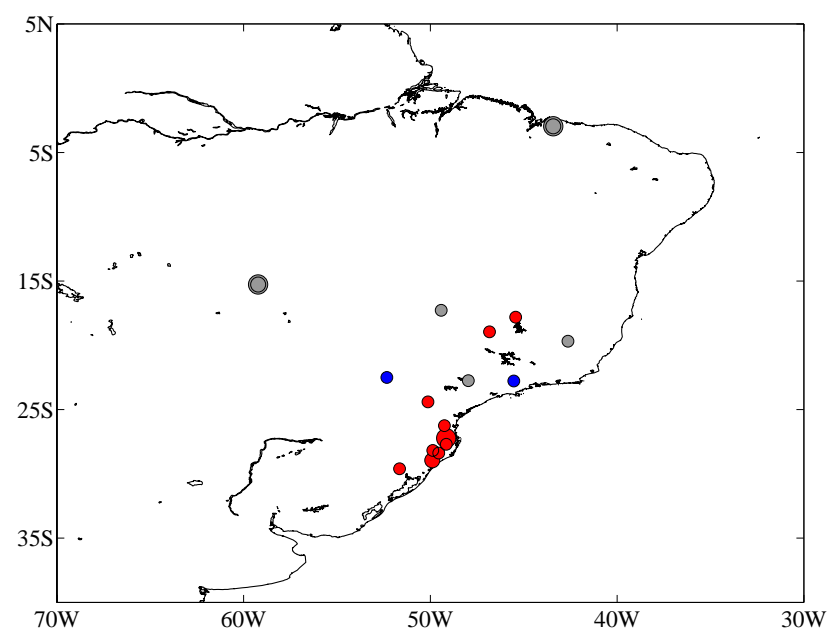

Fig. 7. MH air temperature palaeodata in eastern South America. Symbol colours: blue, colder than present; red, warmer than present; and grey, similar to present. Symbol size refers to palaeodata $Q$ index (a chronological reliability index; see text for more information) values; larger symbols indicate higher $Q$-index values. Vertical axis refers to latitude values, and horizontal axis refers to longitude values.

MH climatic signal described for northeastern Brazil is based on a few records. However, these records show high $Q$-index values (Cruz et al., 2009; Barreto, 2010).

Air temperature records with high $Q$-index values indicate a warmer climate during the $\mathrm{MH}$ if compared to the $\mathrm{LH}$ in southern Brazil, a mixed signal in southeastern Brazil, and similar to LH air temperatures in northeastern Brazil and to the west of $60^{\circ} \mathrm{W}$ (Fig. 7). Proxy records of SST are very few and have intermediate $Q$-index values when compared to land records (Fig. 8). Their scarcity and intermediate $Q$ index values hamper the delivery of a clear scenario for the $\mathrm{MH}$. The only relatively clear scenario can be observed at the NBC, which probably showed warmer SST during the MH if compared to the $\mathrm{LH}$.

When compared to modern climate, our compilation indicates a deficit in the water balance in eastern South America during the $\mathrm{MH}$. With diminished precipitation and enhanced evaporation (less cloudiness), the lake levels were below their modern levels, and air temperatures near the surface were above modern values. These higher air temperatures can be related to less vegetation and to a higher surface albedo. Ocean proxy records revealed saltier waters for the MH than during the LH off eastern South America, mainly close to river mouths such as the La Plata River $\left(35^{\circ} \mathrm{S}\right.$, $\left.57^{\circ} \mathrm{W}\right)$ in northern Argentina and the Doce River $\left(20^{\circ} \mathrm{S}\right.$, $43^{\circ} \mathrm{W}$ ) in southeastern Brazil (Fig. 6). Saltier waters near the coast are generally related to enhanced evaporation and/or reduced river discharge. These features are also related to a drier climate, corroborating the precipitation/moisture, lake levels, and air temperature palaeodata, as well as previous 


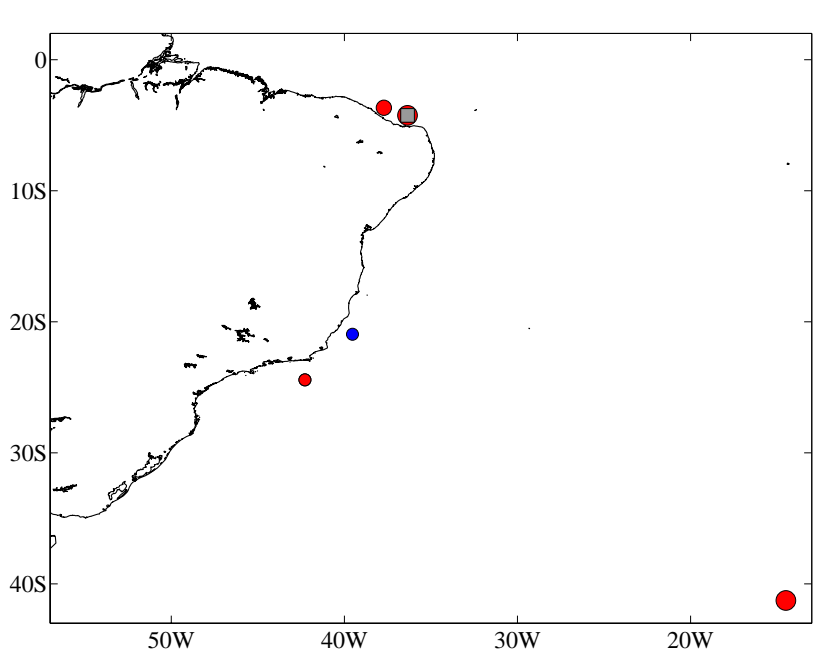

Fig. 8. MH sea surface temperature palaeodata off eastern South America. Symbol colours: blue circles, colder than present; red circles, warmer than present; grey circles, similar to present; and grey squares, warmer-colder oscillation. Symbol size refers to palaeodata $Q$-index (a chronological reliability index; see text for more information) values; larger symbols indicate higher $Q$-index values. Vertical axis refers to latitude values, and horizontal axis refers to longitude values.

studies (Valdes, 2000; Cruz et al., 2009; Silva Dias et al., 2009).

The $\mathrm{BC}$ transports warm waters southward, while the $\mathrm{MC}$ transports cold waters northward, and both are located off eastern South America (e.g. Goni et al., 1996). Consequently, the drier climatic scenario presented here could indicate an equatorward displacement of the Brazil-Malvinas Confluence (BMC) or a decrease in the meridional SST gradient in the western South Atlantic. With the decrease in summer insolation in the Southern Hemisphere during the MH, the South Atlantic Ocean received less energy, which could have been responsible for colder SSTs.

Our methodology points to the speleothem records to be the palaeodata with the highest $Q$-index values. However, as speleothem $\delta^{18} \mathrm{O}$ does not always reflect the precipitation amount, multiproxy compilations are needed to reconstruct clearer past climate signals. Finally, we have identified precipitation as the climatic parameter that shows the most robust MH scenario in eastern South America, mainly because of the large availability and diversity of proxies and palaeorecords related to this variable.

\section{Appendix A}

\section{Abbreviations}

AMO Atlantic Multidecadal Oscillation

AMOC Atlantic Meridional Overturning

Circulation

$\begin{array}{ll}\text { BC } & \text { Brazil Current } \\ \text { BCF } & \text { Brazil Current Front } \\ \text { BH } & \text { Bolivian High } \\ \text { CLIMAP } & \begin{array}{l}\text { Climate: Long-range Investigation, } \\ \text { Mapping, and Prediction }\end{array} \\ \text { CMIP } & \text { Coupled Model Intercomparison Project } \\ \text { COHMAP } & \text { Cooperative Holocene Mapping Projects } \\ \text { ENSO } & \text { El Niño-Southern Oscillation } \\ \text { ITCZ } & \text { Intertropical Convergence Zone } \\ \text { LGM } & \text { Last Glacial Maximum } \\ \text { LH } & \text { Late Holocene } \\ \text { MC } & \text { Malvinas Current } \\ \text { MH } & \text { Mid-Holocene } \\ \text { NBC } & \text { North Brazilian Current } \\ \text { PDO } & \text { Pacific Decadal Oscillation } \\ \text { PMIP } & \text { Paleoclimate Modelling Intercomparison } \\ & \text { Project } \\ \text { SACZ } & \text { South Atlantic Convergence Zone } \\ \text { SALLJ } & \text { South American Low Level Jet } \\ \text { SAM } & \text { Southern Annular Mode } \\ \text { SAMS } & \text { South American monsoon system } \\ \text { SEC } & \text { South Equatorial Current } \\ \text { SECC } & \text { South Equatorial Countercurrent } \\ \text { SEUC } & \text { South Equatorial Undercurrent } \\ \text { SSS } & \text { Sea surface salinity } \\ \text { SST } & \text { Sea surface temperature }\end{array}$

Acknowledgements. This study was funded by the grants 2010/09983-9, 2011/06610-0, and 2012/17517-3, São Paulo Research Foundation (FAPESP); grants 300223/93-5 and 557044/2009-0, CNPq; and 573720/2008, CNPq-MCTI/NCTCriosfera. We would like to acknowledge the help of Elder Yokoyama and Plínio Jaqueto for production of figures. MPL and BT work was in the framework of ANR 2010 BLANC 608-01 ELPASO. We finally would like to acknowledge the anonymous referees for the suggestions and comments that contributed to the improvement of this study.

Edited by: V. Rath

\section{References}

Absy, M. L., Cleef, A., Fournier, M., Martin, L. Servant, M., Sifeddine, A., Silva, M. F., Soubies, F., Suguio, K., Turcq, B., and Van Der Hammen, T.: Mise en évidence de quatre phases d'ouverture de la fôret dense dans de sud-est de l'Amazonie au cours des 60000 dernières années. Première comparaison avec d'autres regions tropicales, C. R. Acad. Sci. Paris, 312, II, 673-678, 1991.

Angulo, R. J., Lessa, G. C., and Souza, M. C.: A critical review of mid- to late-Holocene sea-level fluctuations on the eastern Brazilian coastline, Quaternary Sci. Rev., 25, 486-506, 2006.

Arz, H. W., Pätzold, J., and Wefer, G.: Correlated millennialscale changes in surface hydrography and terrigenous sediment yield inferred from Last-Glacial marine deposits off Northeastern Brazil, Quaternary Res., 50, 157-166, 1998. 
Arz, H. W., Gerhardt, S., Pätzold, and Röhl, U.: Millennial-scale changes of surface- and deep-water flow in the western tropical Atlantic linked to Northern Hemisphere high-latitude climate during the Holocene, Geology, 29, 239-242, 2001.

Barberi, M., Salgado-Labouriau, M. L., and Suguio, K.: Paleovegetation and paleoclimate of "Vereda de Águas Emendadas", central Brazil, J. S. Am. Earth Sci., 13, 241-254, 2000.

Barreto, E. A. S.: Reconstituição da pluviosidade da chapada diamantina (BA) durante o Quaternário tardio através de registros isotópicos ( $\mathrm{O}$ e $\mathrm{C}$ ) em estalagmites, Master Dissertation, Universidade de São Paulo, 2010.

Bartlein, P. J., Harrison, S. P., Brewer, S., Connor, S., Davis, B. A. S., Gajewski, K., Guiot, J., Harrison-Prentice, T. I., Henderson, A., Peyron, O., Prentice, I. C., Scholze, M, Seppä, H., Shuman, B., Sugita, S., Thompson, R. S., Viau, A. E., Williams, J., and $\mathrm{Wu}, \mathrm{H}$.: Pollen-based continental climate reconstructions at 6 and 21 ka: a global synthesis, Clim. Dynam., 37, 775-802, 2011.

Bauermann, S. G., Marques-Toigo, M., Behling, H., and Souza, P. A.: Análises palinológicas da turfeira de Águas Claras, planície costeira do Rio Grande do Sul, Brasil, $9^{\circ}$ Congresso da Associação Brasileira de Estudos do Quaternário, 2003.

Behling, H.: Investigations into the Late Pleistocene and Holocene history of vegetation and climate in Santa Catarina (S Brazil), Veg. Hist. Archaeobot., 4, 127-152, 1995a.

Behling, H.: A high resolution Holocene pollen records from Lago do Pires, SE Brazil: vegetation, climate and fire history, J. Paleolimnol., 14, 253-268, 1995b.

Behling, H.: Late Quaternary vegetation, climate and fire history from the tropical mountain region of Morro de Itapeva, SE Brazil, Palaeogeogr. Palaeocli., 129, 407-422, 1997a.

Behling, H.: Late Quaternary vegetation, climate and fire history of the Araucaria forest and campos region from Serra Campos Gerais, Paraná State (South Brazil), Rev. Palaeobot. Palyno., 97, 109-121, 1997b.

Behling, H.: Late Quaternary environmental changes in the Lagoa da Curuça region (eastern Amazonia, Brazil) and evidence of Podocarpus in the Amazon lowland, Veg. Hist. Archaeobot., 10, 175-183, 2001.

Behling, H.: Late Quaternary vegetation and climate dynamics in southeastern Amazonia inferred from Lagoa da Confusão in Tocantins State, northern Brazil, Amazoniana, 17, 27-39, 2002.

Behling, H.: Late glacial and Holocene vegetation, climate and fire history inferred from Lagoa Nova in the southeastern Brazilian lowland, Veg. Hist. Archaeobot., 12, 263-270, 2003.

Behling, H.: Late Quaternary vegetation, fire and climate dynamics of Serra do Araçatuba in the Atlantic coastal mountains of Paraná State, southern Brazil, Veg. Hist. Archaeobot., 16, 77-85, doi:10.1007/s00334-006-0078-2, 2007.

Behling, H. and Costa, M. L.: Studies on Holocene tropical vegetation mangrove and coast environments in the state of Maranhão, NE Brazil, J. Quat. S. Am. A., 10, 93-118, 1997.

Behling, H. and Costa, M. L.: Holocene environmental changes from the Rio Curuá record in the Caxiuanã region, Eastern Amazon Basin, Quaternary Res., 53, 369-377, 2000.

Behling, H. and Costa, M. L.: Holocene vegetational and coastal environmental changes from the Lago Crispim record in northeastern Pará State, eastern Amazonia, Rev. Palaeobot. Palyno., 114, 145-155, 2001.
Behling, H. and Negrelle, R. B.: Tropical rain forest and climate dynamics of the Atlantic lowland Southern Brazil, during the Late Quaternary, Quaternary Res., 56, 383-389, doi:10.1006/qres.2001.2264, 2001.

Behling, H. and Safford, H. D.: Late-glacial and Holocene vegetation, climate and fire dynamics in the Serra dos Órgãos, Rio de Janeiro State, southeastern Brazil, Glob. Change Biol., 16, 16611671, doi:10.1111/j.1365-2486.2009.02029.x, 2010.

Behling, H., Bauermann, S. G., and Neves, P. C. P.: Holocene environmental changes in the São Francisco de Paula region, southern Brazil, J. S. Am. Earth Sci., 14, 631-639, 2001a.

Behling, H., Cohen, M. C. L., and Lara, R. J.: Studies on Holocene mangrove ecosystem dynamics of the Bragança Peninsula in north-eastern Pará, Brazil, Palaeogeogr. Palaeocl., 167, 225-242, $2001 b$.

Behling, H., Pillar, V. D., Orlóci, L., and Bauermann, S. G.: Late Quaternary Araucaria forest, grassland (Campos), fire and climate dynamics, studied by high-resolution pollen, charcoal and multivariate analysis of the Cambará do Sul core in southern Brazil, Palaeogeogr. Palaeocl., 203, 277-297, 2004.

Behling, H., Pillar, V. D. P., and Bauermann, S. G.: Late Quaternary grassland (Campos), gallery forest, fire and climate dynamics, studied by pollen, charcoal and multivariate analysis of the São Francisco de Assis core in western Rio Grande do Sul (southern Brazil), Rev. Palaeobot. Palyno., 133, 235-248, 2005.

Behling, H., Dupont, L., Safford, H. D., and Wefer, G.: Late Quaternary vegetation and climate dynamics in the Serra da Bocaina, southeastern Brazil, Quatern. Int., 161, 22-31, 2007.

Bosmans, J. H. C., Drijfhout, S. S., Tuenter, E., Lourens, L. J., Hilgen, F. J., and Weber, S. L.: Monsoonal response to midholocene orbital forcing in a high resolution GCM, Clim. Past, 8, 723-740, doi:10.5194/cp-8-723-2012, 2012.

Braconnot, P., Otto-Bliesner, B., Harrison, S., Joussaume, S., Peterchmitt, J.-Y., Abe-Ouchi, A., Crucifix, M., Driesschaert, E., Fichefet, Th., Hewitt, C. D., Kageyama, M., Kitoh, A., Laîné, A., Loutre, M.-F., Marti, O., Merkel, U., Ramstein, G., Valdes, P., Weber, S. L., Yu, Y., and Zhao, Y.: Results of PMIP2 coupled simulations of the Mid-Holocene and Last Glacial Maximum Part 1: experiments and large-scale features, Clim. Past, 3, 261277, doi:10.5194/cp-3-261-2007, 2007a.

Braconnot, P., Otto-Bliesner, B., Harrison, S., Joussaume, S., Peterchmitt, J.-Y., Abe-Ouchi, A., Crucifix, M., Driesschaert, E., Fichefet, Th., Hewitt, C. D., Kageyama, M., Kitoh, A., Loutre, M.-F., Marti, O., Merkel, U., Ramstein, G., Valdes, P., Weber, L., Yu, Y., and Zhao, Y.: Results of PMIP2 coupled simulations of the Mid-Holocene and Last Glacial Maximum - Part 2: feedbacks with emphasis on the location of the ITCZ and mid- and high latitudes heat budget, Clim. Past, 3, 279-296, doi:10.5194/cp-3-279-2007, 2007b.

Braconnot, P., Harrison, S. P., Kageyama, M., Bartlein, P. J., Masson-Delmotte, V., Abe-Ouchi, A., Otto-Bliesner, B., and Zhao, Y.: Evaluation of climate models using palaeoclimatic data, Nature Clim. Change, 2, 417-424, doi:10.1038/nclimate1456, 2012.

Bradley, R. S.: Paleoclimatology: reconstructing climates of the Quaternary, 2nd edition, Academic Press, 613 pp., 1999.

Bush, M. B., Miller, M. C., De Oliveira, P. E., and Colinvaux, P. A.: Two histories of environmental change and human disturbance in eastern lowland Amazonia, The Holocene, 10, 543-553, 
doi:10.1191/095968300672647521, 2000.

Bush, M. B., Silman, M. R., De Toledo, M. B., Listopad, C., Gosling, W. D., Williams, C., De Oliveira, P. E., and Krisel, C.: Holocene fire and occupation in Amazonia: records from two lake districts, Philos. T. Roy. Soc. B., 362, 209-218, doi:10.1098/rstb.2006.1980, 2007.

Carré, M., Azzoug, M., Bentaleb, I., Chase, B. M., Fontugne, M., Jackson, D., Ledru, M.-P., Maldonado, A., Sachs, J. P., and Schauer, A. J.: Mid-Holocene mean climate in the south eastern Pacific and its influence on South America, Quatern. Int., 253, 55-66, doi:10.1016/j.quaint.2011.02.004, 2012.

Carvalho, L. M. V., Jones, C., and Liebmann, B.: The South Atlantic Convergence Zone: intensity, form, persistence, and relationships with intraseasonal to interannual activity and extreme rainfall, J. Climate, 17, 88-108, 2004.

Cassino, R. F.: Reconstituição da vegetação e do clima do Chapadão dos Gerais durante o Holoceno, a partir da análise palinológica da Vereda Laçador, Master Dissertation, Universidade Federal de Minas Gerais, 2011.

Chang, P., Fang, Y., Saravanan, R., Ji, L., and Seidel, H.: The cause of the fragile relationship between the Pacific El Niño and the Atlantic Niño, Nature, 443, 324-328, doi:10.1038/nature05053, 2006.

Chaves, R. R. and Nobre, P.: Interactions between sea surface temperature over the South Atlantic Ocean and the South Atlantic Convergence Zone, Geophys. Res. Lett., 31, L03204, doi:10.1029/2003GL018647, 2004.

Chiessi, C. M., Mulitza, S., Pätzold, J., Wefer, G., and Marengo, J. A.: Possible impact of the Atlantic Multidecadal Oscillation on the South American summer monsoon, Geophys. Res. Lett., 36, L21707, doi:10.1029/2009GL039914, 2009.

Chiessi, C. M., Mulitza, S., Pätzold, J., and Wefer, G.: How different proxies record precipitation variability over southeastern South America, IOP Conf. Series: Earth and Environmental Science, 9, 012007, doi:10.1088/1755-1315/9/1/012007, 2010.

CLIMAP Project Members: The surface of the ice-age Earth, Science, 191, 1131-1144, doi:10.1126/science.191.4232.1131, 1976.

CLIMAP Project Members: Seasonal reconstruction of the Earth's surface at the Last Glacial Maximum, Geol. Soc. Am., Map and Chart Series, 36, 1-18, 1981.

CLIMAP Project Members: The Last Interglacial Ocean, Quaternary Int., 21, 123-224, 1984.

COHMAP Members: Climatic changes of the last 18,000 years: observations and model simulations, Science, 241, 1043-1052, 1988.

Colinvaux, P. A., De Oliveira, P. E., Moreno, J. E., Miller, M. C., and Bush, M. B.: A long pollen record from lowland Amazonia: forest and cooling in glacial times, Science, 274, 85-88, 1996.

Cruz Jr., F. W., Burns, S. J., Karmann, I., Sharp, W. D., Vuille, M., Cardoso, A. O., Ferrari, J. A., Silva Dias, P. L., and Viana Jr., O.: Insolation-driven changes in atmospheric circulation over the past 116,000 years in subtropical Brazil, Nature, 434, 63-66, 2005.

Cruz Jr., F. W., Burns, S. J., Karmann, I., Sharp, W. D., and Vuille, M.: Reconstruction of regional atmospheric circulation features during the late Pleistocene in subtropical Brazil from oxygen isotope composition of speleothems, Earth Planet. Sc. Lett., 248, 495-507, doi:10.1016/j.eps1.2006.06.019, 2006a.
Cruz Jr., F. W., Burns, S. J., Karmann, I., Sharp, W. D., Vuille, M., and Ferrari, J. A.: A stalagmite record of changes in atmospheric circulation and soil processes in the Brazilian subtropics during the Late Pleistocene, Quaternary Sci. Rev., 25, 2749-2761, doi:10.1016/j.quascirev.2006.02.019, 2006b.

Cruz Jr., F. W., Burns, S. J., Jercinovic, M., Karmann, I., Sharp, W. D., and Vuille, M.: Evidence of rainfall variations in Southern Brazil from trace element ratios $(\mathrm{Mg} / \mathrm{Ca}$ and $\mathrm{Sr} / \mathrm{Ca})$ in Late Pleistocene stalagmite, Geochim. Cosmochim. Ac., 71, 2250-2263, doi:10.1016/j.gca.2007.02.005, 2007.

Cruz, F. W., Vuille, M., Burns, S. J., Wang, X., Cheng, H., Werner, M., Lawrence Edwards, R., Karmann, I., Auler, A. S., and Nguyen, H.: Orbitally driven east-west antiphasing of South American precipitation, Nat. Geosci., 2, 210-214, doi:10.1038/NGEO444, 2009.

Czaja, A. and Frankignoul, C.: Observed impact of Atlantic SST anomalies on the North Atlantic Oscillation, J. Climate, 15, 606623, 2002.

Dee, D. P., Uppala, S. M., Simmons, A. J., Berrisford, P., Poli, P., Kobayashi, S., Andrae, U., Balmaseda, M. A., Balsamo, G., Bauer, P., Bechtold, P., Beljaars, A. C. M., van de Berg, L., Bidlot, J., Bormann, N., Delsol, C., Dragani, R., Fuentes, M., Geer, A. J., Haimberger, L., Healy, S. B., Hersbach, H., Hólm, E. V., Isaksen, L., Kallberg, P., Köhler, M., Matricardi, M., McNally, A. P., Monge-Sanz, B. M., Morcrette, J.-J., Park, B.-K., Peubey, C., de Rosnay, P., Tavolato, C., Thépaut, J.-N., and Vitart, F.: The ERA-Interim reanalysis: configuration and performance of the data assimilation system, Q. J. Roy. Meteor. Soc., 137, 553-537, 2011.

De Oliveira, P. E.: A palynological record of Late Quaternary vegetational and climatic change in southeastern Brazil, PhD Dissertation, The Ohio State University, 1992.

De Oliveira, P. E., Barreto, A. M. F., and Suguio, K.: Late Pleistocene/Holocene climatic and vegetational history of the Brazilian caatinga: the fossil dunes of the middle São Francisco River, Palaeogeogr. Palaeocl., 152, 319-337, 1999.

De Toledo, M. B. and Bush, M. B.: A mid-Holocene environmental change in Amazonian savannas, J. Biogeogr., 34, 1313-1326, 2007.

Dickson, R. R. and Brown, J.: The production of North Atlantic Deep Water: sources, rates and pathways, J. Geophys. Res., 99, 12319-12341, 1994.

Enfield, D. B. and Mayer, D. A.: Tropical Atlantic sea surface temperature variability and its relation to El Niño-Southern Oscillation, J. Geophys. Res., 108, 929-945, 1997.

Enfield, D. B., Mestas-Nuñez, A. M., and Trimble, P. J.: The Atlantic multidecadal oscillation and its relation to rainfall and river flows in the continental U.S., Geophys. Res. Lett., 28, 20772080, 2001.

Enters, D., Behling, H., Mayr, C., Dupont, L., and Zolitschka, B.: Holocene environmental dynamics of south-eastern Brazil recorded in laminated sediments of Lago Aleixo, J. Paleolimnol., 44, 265-277, doi:10.1007/s10933-009-9402-z, 2010.

Ferraz-Vicentini, K. R. and Salgado-Labouriau, M. L.: Palynological analysis of a palm swamp in Central Brazil, J. S. Am. Earth Sci., 9, 207-219, 1996.

Garcia, M. J., De Oliveira, P. E., Siqueira, E., and Fernandes, R. S.: A Holocene vegetational and climatic record from the Atlantic rainforest belt of coastal State of São Paulo, SE Brazil, 
Rev. Palaeobot. Palyno., 131, 181-199, 2004.

Garcia, S. R. and Kayano, M. T.: Relação dos sistemas de monção com as variabilidade tropical interanual e multi-decenal, Rev. Bras. Meteorol., 24, 69-86, 2009.

Garreaud, R. D., Vuille, M., Compagnucci, R., and Marengo, J. : Present-day South American climate, Palaeogeogr. Palaeocl., 281, 180-195, doi:10.1016/j.palaeo.2007.10.032, 2009.

Giraudeau, J. and Beaufort, L.: Coccolithophores: from extant populations to fossil assemblages, in: Proxies in Late Cenozoic paleoceanography - Developments in Marine Geology, edited by: Hillaire-Marcel, C. and De Vernal, A., Elsevier, 409-439, 2007.

Goni, G., Kamholz, S., Garzoli, S., and Olson, D.: Dynamics of the Brazil-Malvinas Confluence based on inverted echo sounders and altimetry, J. Geophys. Res., 101, 16273-16289, 1996.

Gouveia, S. E. M., Pessenda, L. C. R., Aravena, R., Boulet, R., Scheel-Ybert, R., Bendassoli, J. A., Ribeiro, A. S., and Freitas, H. A.: Carbon isotopes in charcoal and soils in studies of paleovegetation and climate changes during the late Pleistocene and the Holocene in the southeast and centerwest regions of Brazil, Global Planet. Change, 33, 95-106, 2002.

Groeneveld, J. and Chiessi, C. M.: $\mathrm{Mg} / \mathrm{Ca}$ of Globorotalia inflata as a recorder of permanent thermocline temperatures in the South Atlantic, Paleoceanography, 26, PA2203, doi:10.1029/2010PA001949, 2011.

Harrison, S. P., Kutzbach, J E., Liu, Z., Bartlein, P. J., OttoBliesner, B., Muhs, D., Prentice, I. C., and Thompson, R. S.: Mid-Holocene climates of the Americas: a dynamical response to changed seasonality, Clim. Dynam., 20, 663-688, doi:10.1007/s00382-002-0300-6, 2003.

Hassan, G. S., Espinosa, M. A., and Isla, F. I.: Diatom-based inference model for paleosalinity reconstructions in estuaries along the northeastern coast of Argentina, Palaeogeogr. Palaeocl., 275, 77-91, 2009.

Hughen, K. A., Eglinton, T. I., Xu, L., and Makou, M.: Abrupt tropical vegetation response to rapid climate changes, Science, 304, 1955-1959, doi:10.1126/science.1092995, 2004.

Huntley, B.: Reconstructing palaeoclimates from biological proxies: some often overlooked sources of uncertainty, Quaternary Sci. Rev., 31, 1-16, doi:10.1016/j.quascirev.2011.11.006, 2012.

Iriarte, J.: Vegetation and climate change since $14,81014 \mathrm{C}$ yr B.P. in southeastern Uruguay and implications for the rise of early Formative societies, Quaternary Res., 65, 20-32, 2006.

Iriarte, J., Holst, I., Marozzi, O., Listopad, C., Alonso, E., Rinderknecht, A., and Montaña, J.: Evidence for cultivar adoption and emerging complexity during the mid-Holocene in the La Plata Basin, Nature, 432, 614-617, 2004.

Irion, G., Bush, M. B., Nunes de Mello, J. A., Stüben, D., Neumann, Müller, G., Morais de, J. O., and Junk, J. W.: A multiproxy palaeoecological record of Holocene lake sediments from the Rio Tapajós, eastern Amazonia, Palaeogeogr. Palaeocl., 240, 523-535, doi:10.1016/j.palaeo.2006.03.005, 2006.

Jacob, J., Disnar, J.-R., Boussafir, M., Sifeddine, A., Turcq, B., and Albuquerque, A. L. S.: Major environmental changes recorded by lacustrine sedimentary organic matter since the last glacial maximum near the equator (Lagoa do Caçó, NE Brazil), Palaeogeogr. Palaeocl., 205, 183-197, doi:10.1016/j.palaeo.2003.12.005, 2004.

Jaeschke, A., Rühlemann, C., Arz, H., Heil, G., and Lohmann, G.: Coupling of millennial-scale changes in sea surface temperature and precipitation off northeastern Brazil with high-latitude climate shifts during the last glacial period, Paleoceanography, 22, PA4206, doi:10.1029/2006PA001391, 2007.

Jansen, E., Overpeck, J., Briffa, K. R., Duplessy, J.-C., Joos, F., Masson-Delmotte, V., Olago, D., Otto-Bliesner, B., Peltier, W. R., Rahmstorf, S., Ramesh, R., Raynaud, D., Rind, D., Solomina, O., Villalba, R., and Zhang, D.: Palaeoclimate, in: Climate Change 2007: The Physical Science Basis. Contribution of Working Group I to the Fourth Assessment Report of the Intergovernmental Panel on Climate Change, edited by: Solomon, S., Qin, D., Manning, M., Chen, Z., Marquis, M., Averyt, K. B., Tignor, M., and Miller, H. L., Cambridge University Press, Cambridge, United Kingdom and New York, NY, USA, 497 pp., 2007.

Joussaume, S. and Braconnot, P.: Sensitivity of paleoclimate simulation results to season definitions, J. Geophys. Res., 102, 1943 1956, 1997.

Kageyama, M., Laîne, A., Abe-Ouchi, A., Braconnot, P., Cortijo, E., Crucifix, M., De Vernal, A., Guiot, J., Hewitt, C. D., Kitoh, A., Kucera, M., Marti, O., Ohgaito, R., Otto-Bliesner, B., Peltier, W. R., Rosell-Melé, A., Vettoretti, G., Weber, S. L., and Yu, Y.: Last Glacial Maximum temperatures over the North Atlantic, Europe and western Siberia: a comparison between PMIP models, MARGO sea-surface temperatures and pollen-based reconstructions, Quaternary Sci. Rev., 25, 2082-2102, 2006.

Kohfeld, K. E. and Harrison, S. P.: How well can we simulate past climates? Evaluating the models using global palaeoenvironmental datasets, Quaternary Sci. Rev., 19, 321-346, 2000.

Kohfeld, K. E. and Harrison, S. P.: DIRTMAP: the geological record of dust, Earth Sci. Rev., 54, 81-114, 2001.

Kucera, M., Rosell-Melé, A., Schneider, R., Waelbroeck, C., and Weinelt, M.: Multiproxy approach for the reconstruction of the glacial ocean surface (MARGO), Quaternary Sci. Rev., 24, 813 819, 2005.

Kuhlbrodt, T., Griesel, A., Montoya, M., Levermann, A., Hofmann, M., and Rahmstorf, S.: On the driving processes of the Atlantic Meridional Overturning circulation, Rev. Geophys., 45, 1-32, 2007.

Leal, M. G. and Lorscheitter, M. L.: Plant succession in a forest on the Lower Northeast Slope of Serra Geral, Rio Grande do Sul, and Holocene palaeoenvironments, Southern Brazil. Acta Bot. Bras., 21, 1-10, 2007.

Ledru, M.-P.: Late Quaternary environmental and climatic changes in central Brazil, Quaternary Res., 39, 90-98, 1993.

Ledru, M.-P., Cordeiro, R. C., Dominguez, J. M. L., Martin, L., Mourguiart, P., Sifeddine, A., and Turcq, B.: Late-glacial cooling in Amazonia inferred from pollen at Lagoa do Caçó, Northern Brazil, Quaternary Res., 55, 47-56, doi:10.1006/qres.2000.2187, 2001.

Ledru, M.-P., Mourguiart, P., Ceccantini, G., Turcq, B., and Sifeddine, A.: Tropical climates in the game of two hemispheres revealed by abrupt climatic change, Geology, 30, 275-278, 2002.

Ledru, M.-P., Rousseau, D.-D., Cruz Jr., F. W., Riccomini, C., Karmann, I., and Martin, L.: Paleoclimate changes during the last $100,000 \mathrm{yr}$ from a record in the Brazilian Atlantic rainforest region and interhemispheric comparison, Quaternary Res., 64, 444-450, 2005.

Ledru, M.-P., Ceccantini, G., Gouveia, S. E. M., López-Sáez, J. A., Pessenda, L. C. R., and Ribeiro, A. S.: Millennial-scale cli- 
matic and vegetation changes in a northern Cerrado (Northeast, Brazil) since the Last Glacial Maximum, Quaternary Sci. Rev., 25, 1110-1126, 2006.

Ledru, M.-P., Mourguiart, P., and Riccomini, C.: Related changes in biodiversity, insolation and climate in the Atlantic rainforest since the last interglacial, Palaeogeogr. Palaeocl., 27, 140-152, 2009.

Leduc, G, Schneider, R., Kim, J. H., and Lohmann, G.: Holocene and Eemian sea surface temperature trends as revealed by alkenone and $\mathrm{Mg} / \mathrm{Ca}$ paleothermometry, Quaternary Sci. Rev., 29, 989-1004, doi:10.1016/j.quascirev.2010.01.004, 2010.

Lenters, J. D. and Cook, K. H.: Simulation and diagnosis of the regional summertime precipitation climatology of South America, J. Climate, 8, 2988-3005, 1995.

Lenters, J. D. and Cook, K. H.: On the origin of the Bolivian High and related circulation features of the South American climate, J. Atmos. Sci., 54, 656-677, 1997.

Locarnini, R. A., Mishonov, A. V., Antonov, J. I., Boyer, T. P., Garcia, H. E., Baranova, O. K., Zweng, M. M., and Johnson, D. R.: World Ocean Atlas 2009, Volume 1: Temperature, S. Levitus, Ed. NOAA Atlas NESDIS 68, U. S. Government Printing Office, Washington, D. C., 184 pp., 2010.

Lorente, F. L., Meyer, K. E. B., and Horn, A. H.: Análise palinológica de vereda da Fazenda Urbano, município de Buritizeiro, Minas Gerais, Brasil, Geonomos, 18, 57-72, 2010.

Mantua, N. J., Hare, S. R., Zhang, Y., Wallace, J. M., and Francis, R. C.: A Pacific interdecadal climate oscillation with impacts on salmon production, B. Am. Meteor. Soc., 78, 1069-1079, 1997.

MARGO Project Members: Constraints on the magnitude and patterns of ocean cooling at the Last Glacial Maximum, Nat. Geosci., 2, 127-132, doi:10.1038/NGEO411, 2009.

Marengo, J. A., Soares, W., Saulo, W., and Nicolini, M.: Climatology of the LLJ east of the Andes as derived from the NCEP reanalyses, J. Climate, 17, 2261-2280, 2004.

Marengo, J. A., Liebmann, B., Grimm, A. M., Misra, V., Silva Dias, P. L., Cavalcanti, I. F. A., Carvalho, L. M. V., Berbery, E. H., Ambrizzi, T., Vera, C. S., Saulo, A. C., Nogues-Paegle, J., Zipser, E., Seth, A., and Alves, L. M.: Recent developments on the South American Monsoon system, Int. J. Climatol., 32, 1-21, doi:10.1002/joc.2254, 2012.

Mayle, F. E., Burbridge, R., and Killeen, T. J.: Millennial-scale dynamics of southern Amazonian rain forests, Science, 290, 22912294, doi:10.1126/science.290.5500.2291, 2000.

Melo, M. L. D. and Marengo, J. A.: The influence of changes in orbital parameters over South American climate using the CPTEC AGCM: simulation of climate during the mid-Holocene, The Holocene, 18, 501-516, 2008.

Moro, R. S., Bicudo, C. E. M., Melo, M. S., and Schmitt, J.: Paleoclimate of the late Pleistocene and Holocene at Lagoa Dourada, Paraná State, southern Brazil, Quatern. Int., 114, 87-99, 2004.

Nagai, R. H., Sousa, S. H. M., Burone, L., and Mahiques, M. M.: Paleoproductivity changes during the Holocene in the inner shelf of Cabo Frio, southeastern Brazilian continental margin: benthic foraminifera and sedimentological proxies, Quatern. Int., 206, 62-71, doi:10.1016/j.quaint.2008.10.014, 2009.

Oliveira, M. A. T., Behling, H., and Pessenda, L. C. R.: LatePleistocene and mid-Holocene environmental changes in highland valley head areas of Santa Catarina State, Southern Brazil, J. S. Am. Earth Sci., 26, 55-67, 2008a.
Oliveira, M. A. T., Behling, H., Pessenda, L. C. R., and Lima, G. L.: Stratigraphy of near-valley head quaternary deposits and evidence of climate-driven slope-channel processes in Southern Brazilian highlands, Catena, 75, 77-92, 2008b.

Parizzi, M. G., Salgado-Labouriau, M. L., and Kohler, H. C.: Genesis and environment history of Lagoa Santa, southeastern Brazil, The Holocene, 8, 311-321, 1998.

Parolin, M., Medeanic, S., and Stevaux, J. C.: Registros palinológicos e mudanças ambientais durante o Holoceno de Taquarussu (MS), Rev. Bras. Paleontol., 9, 137-148, 2006.

Peixoto, J. P. and Oort, A. H.: Physics of climate, Springer-Verlag, 520 pp., 1992.

Pessenda, L. C. R., Aravena, R., Melfi, A. J., Telles, E. C. C., Boulet, R., Valencia, E. P. E., and Tomazello, M.: The use of carbon isotopes $(13 \mathrm{C}, 14 \mathrm{C})$ in soil to evaluate vegetation changes during the Holocene in Central Brazil, Radiocarbon, 38, 191-201, 1996.

Pessenda, L. C. R., Gouveia, S. E. M., Aravena, R., Boulet, R., and Valencia, E. P. E.: Holocene fire and vegetation changes in southeastern Brazil as deduced from fossil charcoal and soil carbon isotopes, Quatern. Int., 114, 35-43, doi:10.1016/S10406182(03)00040-5, 2004a.

Pessenda, L. C. R., Ribeiro, A. S., Gouveia, S. E. M., Aravena, R., Boulet, R., and Bendassolli, J. A.: Vegetation dynamics during the late Pleistocene in the Barreirinhas region, Maranhão State, northeastern Brazil, based on carbon isotopes in soil organic matter, Quaternary Res., 62, 183-193, doi:10.1016/j.yqres.2004.06.003, 2004b.

Pessenda, L. C. R., Ledru, M.-P., Gouveia, S. E. M., Aravena, R., Ribeiro, A. S., Bendassolli, J. A., and Boulet, R.: Holocene palaeoenvironmental reconstruction in northeastern Brazil inferred from pollen, charcoal and carbon isotope records, The Holocene, 15, 812-820, doi:10.1191/0959683605hl855ra, 2005.

Pessenda, L. C. R., De Oliveira, P. E., Mofatto, M., Medeiros, V. B., Garcia, R. J. F., Aravena, R., Bendassoli, J. A., Leite, A. Z., Saad, A. R., and Etchebehere, M. L.: The evolution of a tropical rainforest/grassland mosaic in southeastern Brazil since 28,000 14C yr BP based on carbon isotopes and pollen records, Quaternary Res., 71, 437-452, doi:10.1016/j.yqres.2009.01.008, 2009.

Peterson, R. G. and Stramma, L.: Upper-level circulation in the South Atlantic Ocean, Prog. Oceanog., 26, 1-73, 1991.

Pinot, S., Ramstein, G., Harrison, S. P., Prentice, I. C., Guiot, J., Stute, M., and Joussaume, S.: Tropical paleoclimates at the Last Glacial Maximum: comparison of Paleoclimate Modeling Intercomparison Project (PMIP) simulations and paleodata, Clim. Dynam., 15, 857-874, 1999.

Pivel, M. A. G., Toledo, F. A. L., and Costa, K. B.: Foraminiferal record of changes in summer monsoon precipitation at the southeastern Brazilian continental margin since the Last Glacial Maximum, Rev. Bras. Paleontol., 13, 79-88, doi:10.4072/rbp.2010.2.01, 2010.

Power, M. J., Marlon, J., Ortiz, N., Bartlein, P. J., Harrison, S. P., Mayle, F. E., Ballouche, A., Bradshaw, R. H. W., Carcaillet, C., Cordova, C., Mooney, S., Moreno, P. I., Prentice, I. C., Thonicke, K., Tinner, W., Whitlock, C., Zhang, Y., Zhao, Y., Ali, A. A., Anderson, R. S., Beer, R., Behling, H., Briles, C., Brown, K . J., Brunelle, A., Bush, M., Camill, P., Chu, G. Q., Clark, J., Colombaroli, D., Connor, S., Daniau, A.-L., Daniels, M., Dodson, J., Doughty, E., Edwards, M. E., Finsinger, W., Foster, D., Frechette, J., Gaillard, m.-J., Gavin, D. G., Gobet, E., Haberle, 
S., Hallett, D. J., Higuera, P., Hope, G., Horn, S., Inoue, J., Kaltenrieder, P., Kennedy, L. Kong, Z. C., Larsen, C., Long, C. J., Lynch, J., Lynch, E. A., McGlone, M., Meeks, S., Mensing, S., Meyer, G., Minckley, T., Mohr, J., Nelson, D. M., New, J., Newnham, R., Noti, R., Oswald, W., Pierce, J., Richard, P. J. H., Rowe, C., Sanchez Goñi, M. F., Shuman, B. N., Takahara, H., Toney, J., Turney, C., Urrego-Sanchez, D. H., Umbanhowar, C., Vandergoes, M., Vanniere, B., Vescovi, E., Walsh, M., Wang, X., Williams, N., Wilmshurst, J., and Zhang, J. H.: Changes in fire regimes since the Last Glacial Maximum: an assessment based on a global synthesis and analysis of charcoal data, Clim. Dynam., 30, 887-907, doi:10.1007/s00382-007-0334-x, 2008.

Prentice, I. C. and Webb III, T.: BIOME 6000: reconstructing global mid-Holocene vegetation patterns from palaeoecological records, J. Biogeogr., 25, 997-1005, doi:10.1046/j.13652699.1998.00235.x, 1998.

Prieto, A. R.: Late Quaternary vegetational and climatic changes in the Pampa grassland of Argentina, Quaternary Res., 45, 75-88, 1996.

Prieto, A. R., Blasi, A. M., De Francesco, C. G., and Fernández, C.: Environmental history since 11,000 14C yr B.P. of the northeastern Pampas, Argentina, from alluvial sequences of the Luján River, Quaternary Res., 62, 146-161, 2004.

Reboita, M. S., Rocha, R. P., Ambrizzi, T., and Sugahara, S.: South Atlantic Ocean cyclogenesis climatology simulated by regional climate model (RegCM3), Clim. Dynam., 35, 1331-1347, doi:10.1007/s00382-009-0668-7, 2010.

Salas-Melia, D., Chauvin, F., Déqué, M., Douville, H., Gueremy, J., Marquet, P., Planton, S., Royer, J., and Tyteca, S.: Description and validation of the CNRM-CM3 global coupled model, Technical Report 103, CNRM, Météo-France, Toulouse, 36 pp. 2005.

Salgado-Labouriau, M. L., Casseti, V., Ferraz-Vicentini, K. R., Martin, L., Soubiès, F., Suguio, K., and Turcq, B.: Late Quaternary vegetational and climatic changes in cerrado and palm swamp from Central Brazil, Palaeogeogr. Palaeocl., 128, 215-226, 1997.

Scheel-Ybert, R., Gouveia, S. E. M., Pessenda, L. C. R., Aravena, R., Coutinho, L. M., and Boulet, R.: Holocene palaeoenvironmental evolution in the São Paulo State (Brazil), based on anthracology and soil d13C analysis, The Holocene, 13, 73-81, doi:10.1191/0959683603hl596rp, 2003.

Servant, M., Maley, J., Turcq, B., Absy, M. L., Brenac, P., Fournier, M., and Ledru, M.-P.: Tropical forest changes during the Late Quaternary in African and South American lowlands, Global Planet. Change, 7, 25-40, 1993.

Sifeddine, A., Bertrand, P., Fournier, M., Martin, L., Servant, M., Soubies, F., Suguio, K., and Turcq, B.: La sédimentation organique lacustre en milieu tropical humide (Carajas, Amazonie orientale, Brésil): relation avec les changements climatiques au cours des 60,000 derníères années, Bull. Soc. Géol. France, 165, 613-621, 1994.

Sifeddine, A., Martin, L., Turcq, B., Volkmer-Ribeio, C., Soubiès, F., Cordeiro, R. C., and Suguio, K.: Variations of the Amazonian rainforest environment: a sedimentological record covering 30,000 years, Palaeogeogr. Palaeocl., 168, 221-235, 2001.

Sifeddine, A., Wirrmann, D., Albuquerque, A. L. S., Turcq, B., Cordeiro, R. C., Gurgel, M. H.C., and Abrão, J. J.: Bulk composition of sedimentary organic matter used in palaeoenvironmental reconstructions: examples from the tropical belt of South America and Africa, Palaeogeogr. Palaeocl., 214, 41-53, doi:10.1016/j.palaeo.2004.06.012, 2004.

Silva, G. A. M., Drumond, A., and Ambrizzi, T.: The impact of El Niño on South American summer climate during different phases of the Pacific Decadal Oscillation, Theor. Appl. Climatol., 106, 307-319, doi:10.1007/s00704-011-0427-7, 2011.

Silva Dias, P. L., Turcq, B., Silva Dias, M. A. F., Braconnot, P., and Jorgetti, T.: Mid-Holocene climate of tropical South America: a model-data approach, in: Past climate variability from the Last Glacial Maximum to the Holocene in South America and surrounding regions, edited by: Vimeux, F., Sylvestre, F., and Khodri, M., Springer-Verlag, 259-281, 2009.

Smith, C. B, Cohen, M. C. L., Pessenda, L. C. R., França, M. C., Guimarães, J. T. F., Rossetti, D. F., and Lara, R. J.: Holocene coastal vegetational changes at the mouth of the Amazon River, Rev. Palaeobot. Palyno., 168, 21-30, doi:10.1016/j.revpalbo.2011.09.008, 2011.

Srokosz, M., Baringer, M., Bryden, H., Cunningham, S., Delworth, T., Lozier, S., Marotzke, J., and Sutton, R.: Past, present, and future changes in the Atlantic Meridional Overturning circulation, B. Amer. Meteor. Soc., 93, 1663-1676, doi:10.1175/BAMS-D11-00151.1, 2012.

Stevaux, J. C.: Climatic events during the Late Pleistocene and Holocene in the Upper Parana River: correlation with NE Argentina and South-Central Brazil. Quatern. Int., 72, 73-85, 2000.

Stríkis, N. M., Cruz, F. W., Cheng, H., Karmann, I., Lawrence Edwards, R., Vuille, M., Wang, X., De Paula, M. S., Novello, V. F., and Auler, A. S.: Abrupt variations in South American monsoon rainfall during the Holocene based on a speleothems record from central-eastern Brazil, Geology, 39, 1075-1078, doi:10.1130/G32098.1, 2011.

Takahashi, K. and Battisti, D. S.: Processes controlling the mean tropical Pacific precipitation pattern. Part I: the Andes and the eastern Pacific ITCZ, J. Climate, 20, 3434-3451, doi:10.1175/JCLI4198.1, 2007.

Talley, L. D., Pickard, G. L., Emery, W. J., and Swift, J. H.: Descriptive physical oceanography: an introduction, Elsevier, 6th Ed., 555 pp., 2011.

Taylor, K. E., Stouffer, R. J., and Meehl, G. A.: An overview of CMIP5 and the experiment design, B. Am. Meteor. Soc., 93, 485-498, doi:10.1175/BAMS-D-11-00094.1, 2012.

Toledo, F. A. L., Costa, K. B., and Pivel, M. A. G.: Salinity changes in the western tropical South Atlantic during the last $30 \mathrm{kyr}$, Global Planet. Change, 57, 383-395, 2007.

Toledo, F. A. L., Costa, K. B., Pivel, M. A. G., and Campos, E. J. D.: Tracing past circulation changes in the western South Atlantic based on planktonic foraminifera, Rev. Bras. Paleontol, 11, 169178, doi:10.4072/rbp.2008.3.03, 2008.

Trenberth, K. E.: The definition of El Niño, B. Am. Meteor. Soc., 78, 2771-2777, 1997.

Turcq, B., Pressinotti, M. M. N., and Martin, L.: Paleohydrology and paleoclimate of the past 33,000 years at the Tamanduá River, Central Brazil, Quaternary Res., 47, 284-294, 1997.

Turcq, B., Albuquerque, A. L. S., Cordeiro, R. C., Sifeddine, A., Simões Filho, F. F. L., Souza, A. G., Abrão, J. J., Oliveira, F. B. L., Silva, A. O., and Capitâneo, J.: Accumulation of organic carbon in five Brazilian lakes during the Holocene, Sediment. Geol., 148, 319-342, 2002.

Valdes, P. J.: South American palaeoclimate model simulations: how reliable are the models?, J. Quaternary. Sci., 15, 357-368, 
2000.

Venegas, S. A., Mysak, L. A., and Straub, D. N.: An interdecadal climate cycle in the South Atlantic and its links to other ocean basins, J. Geophys. Res., 103, 24723-24736, 1998.

Vera, C., Higgins, W., Amador, J., Ambrizzi, T., Garreaud, R., Gochis, D., Gutzler, D., Lettenmaier, D., Marengo, J., Mechoso, C. R., Nogues-Paegle, J., Silva Dias, P. L., and Zhang, C.: Toward a unified view of the American Monsoon Systems, J. Climate, 19, 4977-5000, 2006.

Vilanova, I., Prieto, A. R., and Espinosa, M.: Palaeoenvironmental evolution and sea-level fluctuations along the southeastern Pampa grasslands coast of Argentina during the Holocene, J. Quaternary Sci., 21, 227-242, doi:10.1002/jqs.953, 2006.

Visbeck, M.: A station-based Southern Annular Mode Index from 1884 to 2005, J. Climate, 22, 940-950, doi:10.1175/2008JCLI2260.1, 2009.

Vuille, M., Burns, S. J., Taylor, B. L., Cruz, F. W., Bird, B. W., Abbott, M. B., Kanner, L. C., Cheng, H., and Novello, V. F.: A review of the South American monsoon history as recorded in stable isotopic proxies over the past two millennia, Clim. Past, 8, 1309-1321, doi:10.5194/cp-8-1309-2012, 2012.

Wainer, I., Gent, P., and Goni, G.: Annual cycle of the BrazilMalvinas confluence region in the National Center for Atmospheric Research Climate System Model, J. Geophys. Res., 105, 26167-16177, 2000.

Wainer, I., Clauzet, G., Ledru, M.-P., Brady, E., and Otto-Bliesner, B.: Last Glacial Maximum in South America: Paleoclimate proxies and model results, Geophys. Res. Lett., 32, L08702, doi:10.1029/2004GL021244, 2005.

Wainer, I., Servain, J., and Clauzet, G.: Is the decadal variability in the tropical Atlantic a precursor to the NAO?, Ann. Geophys., 26, 4075-4080, doi:10.5194/angeo-26-4075-2008, 2008.
Wang, X., Auler, A. S., Lawrence Edwards, R., Cheng, H., Ito, E., and Solheid, M.: Interhemispheric anti-phasing of rainfall during the last glacial period, Quaternary Sci. Rev., 25, 3391-3403, doi:10.1016/j.quascirev.2006.02.009, 2006.

Wang, X., Auler, A. S., Edwards, R. L., Cheng, H., Ito, E., Wang, Y., Kong, X., and Solheid, M.: Millennial-scale precipitation changes in southern Brazil over the past 90,000 years, Geophys. Res. Lett., 34, L23701, doi:10.1029/2007GL031149, 2007.

Weldeab, S., Schneider, R. R., and Kölling, M.: Deglacial sea surface temperature and salinity increase in the western tropical Atlantic in synchrony with high latitude climate instabilities, Earth Planet. Sci. Lett., 241, 699-706, 2006.

Whitney, B. S., Mayle, F. E., Punyasena, S. W., Fitzpatrick, K. A., Burn, M. J., Guillen, R., Chavez, E., Mann, D., Pennington, R. T., and Metcalfe, S. E.: A 45 kyr Palaeoclimate record from the lowland interior of tropical South America, Palaeogeogr. Palaeocl., 307, 177-192, doi:10.1016/j.palaeo.2011.05.012, 2011.

Wirtz, K. W., Lohmann, G., Bernhardt, K., and Lemmen, C.: MidHolocene regional reorganization of climate variability: analyses of proxy data in the frequency domain, Palaeogeogr. Palaeocl., 298, 189-200, doi:10.1016/j.palaeo.2010.09.019, 2010.

Zebiak, S. E.: Air-sea interaction in the equatorial Atlantic region, J. Climate, 6, 1567-1586, 1993.

Zech, W., Zech, M., Zech, R., Peinemann, N., Morrás, H. J. M., Moretti, L., Ogle, N., Kalim, R. M., Fuchs, M., Schad, P., and Glaser, B.: Late Quaternary palaeosol records from subtropical $\left(38^{\circ} \mathrm{S}\right)$ to tropical $\left(16^{\circ} \mathrm{S}\right)$ South America and palaeoclimatic implications, Quatern. Int., 196, 107-120, doi:10.1016/j.quaint.2008.01.005, 2009.

Zhou, J. and Lau, K.-M.: Does a monsoon climate exist over South America?, J. Climate, 11, 1020-1040, 1998. 